Article

\title{
Technical Evaluation of a PV-Diesel Hybrid System with Energy Storage: Case Study in the Tapajós-Arapiuns Extractive Reserve, Amazon, Brazil ${ }^{\dagger}$
}

\author{
Tatiane Silva Costa $*$ $\ddagger$ (D) and Marcelo Gradella Villalva $\ddagger$ \\ LESF Laboratory of Energy and Photovoltaic Systems, School of Electrical and Computer Engineering, \\ University of Campinas, Albert Einstein Avenue, 400, Campinas 13083-970, Brazil; villalva@unicamp.br \\ * Correspondence: tati_costa@rocketmail.com or t209426@dac.unicamp.br \\ † 2019 IEEE PES Innovative Smart Grid Technologies Conference-Latin America (ISGT Latin America), \\ Gramado, Brazil, 15-18 September 2019; pp. 1-6, doi:10.1109/ISGT-LA.2019.8895273. \\ $\ddagger$ These authors contributed equally to this work.
}

Received: 8 May 2020; Accepted: 4 June 2020; Published: 9 June 2020

\begin{abstract}
In 2018 the number of people without access to electricity dropped to less than 1 billion. However, the difficulty of serving these people became higher, as the locations are in the most remote areas of the world. Brazil, for example, needs to bring electricity to around 1 million people who, in the vast majority, live within the Amazon region. In this way, hybrid energy systems (HESs) count as an attractive alternative for power generation, especially in remote areas. Therefore, this article analyzes a case study of a hybrid photovoltaic-diesel system installed in the Tapajós-Arapiuns Extractive Reserve in the Brazilian Amazon region. The studied plant is composed of a photovoltaic (PV) system, a lead-acid electrochemical battery bank, a diesel generator, and electro-electronic loads with highly variable demand throughout the year. The HOMER PRO software is used as the simulation tool. The results show that the load following dispatch strategy is the best option, with $85.6 \%$ of the load demand being supplied by PV energy and only $14.4 \%$ by the diesel generator set. As a result, the system is technically feasible to be replicated as a reliable energy source in other areas of the reserve to supply schools, public health places, and other community services.
\end{abstract}

Keywords: hybrid energy system; photovoltaic; wind; diesel generator; Amazon; remote areas

\section{Introduction}

Universal access to electricity has increased exponentially in recent decades. In the early 1990s, approximately $71 \%$ of the global population had access to energy. About 26 years later, in 2016, this number reached over $87 \%$. However, 940 million people in that year still remained without any energy support. The number of people without access to electricity dropped from almost 1 billion in 2017 to 860 million in 2018 [1-3]. These data are extremely significant, but the challenge becomes higher as the populations who still need to be served are located in remote areas of the world. The crucial solutions to serve these populations predominate in the use of renewable sources such as solar and wind for the implantation of individual energy systems or hybrid systems.

Among other remote areas of the world, the Amazon imposes significant difficulties to the electricity supply. The Amazon region is characterized by its size, biodiversity, range of natural resources, and its population. Its population is mainly composed of traditional and rural communities. These populations are used to building small communities next to the forests, mainly on river channels that provide the inhabitants with locomotion and food. 
Consequently, the benefits of using electricity do not reach these populations, from the simple access to primary means of communication to the precariousness of education, and the lack of the minimum housing conditions necessary for every citizen. The communities still use the old kerosene or carbide lamp as their primary light source at night. Although the Brazilian Federal Government launched in November 2003 the Light for All Program (Programa Luz para Todos) for universal access to electric energy throughout the country, the reality of this population remains almost unchanged on many issues.

The universalization of electric energy in Brazil still presents significant obstacles to achieving the United Nations (UN) sustainable development objective-7. In 2019 the number of people outside the national electric grid in the Brazilian Amazon was estimated to be near 990 thousand inhabitants. In the same year, the Ministry of Mines and Energy announced that it would take 7 to 10 years to serve 72 thousand families in this region. Since the beginning of the Light for All program, only 3000 families in these areas received aid through the Green Extractive Reserve Forever (Reserva Extrativista Verde para Sempre) program in the region of Pará [4].

Policies aimed at providing energy to isolated areas have many limitations that preclude any small-scale initiatives. Nevertheless, this reality has been changing in recent years. To meet the basic needs of some communities, non-governmental institutions have implemented solar energy system for water pumping, public lighting, electrification of schools, health places, and community centers. These applications occur with individual photovoltaic systems, mini-grids, or hybrid energy systems (HESs).

In this paper, the topic covered is hybrid photovoltaic systems for remote areas of the Amazon region. The application of HESs in the country occurs more frequently in remote areas, where there is a low demand for energy for production and residential use, making the service of this population unattractive to energy utilities. The national electric grid cannot offer the service, due to difficulties in access, cost of building substations, transmission, and distribution lines to meet a low demand [5-8]. Due to the unavailability of the electricity grid, the population living in these places finds diesel generator sets as a solution, which guarantees a few hours of electricity per day. However, diesel generators present too many problems over their useful life. Hybrid systems with the use of photovoltaic and wind systems combined with diesel generators in autonomous HESs guarantee less dependence on fossil fuel, less emission of greenhouse gases, higher reliability, better quality, and less oscillation in the delivery of energy to the final load. However, the proper selection of technology and the sizing of the generation unit are essential in the design of these systems to improve operational performance and dispatch control [9-12].

In research on hybrid energy systems, it is possible to list a series of works and articles that show the importance of this field of study. Hauschild [13] addresses the evaluation of operating strategies for hybrid photovoltaic-wind-diesel systems in two case studies in Ilha do Cardoso, in the state of São Paulo (Brazil) and the results are used to determine the best strategies. Lau [14] analyzes the potential use of a hybrid photovoltaic-diesel system in remote locations in Malaysia. He uses the HOMER software to study the technical and economic feasibility of the hybrid PV/diesel energy system. Barbosa [15] contributes by raising the technical, operational, economic, and management characteristics of hybrid energy systems implemented in the Amazon Region to model operating strategies. In the work of Sandeep [16], HOMER is used for designing and finding an optimized configuration of a hybrid power system in terms of stability, economy, size, and the number of components, before installation. The simulated results using the software provide a comparative economic analysis of each configuration and evaluate the best configuration. Thus, HOMER is advantageous in carrying out the configuration and the energy balance for each hour to choose whether the configuration is viable. Singh [17] uses the software to analyze the design, cost optimization, and control strategy of a hybrid energy system. Other authors [18-23] present different methodologies for decision making based on an optimal cost analysis for the planning of several hybrid energy systems. These works analyze the impacts of hybrid systems considering different renewable energy sources 
(wind, solar, and hydro) to determine the optimal solution corresponding to a minimum annualized cost of capital. Many other authors also present works in the areas of autonomous HESs [6,21,23-26].

The main contribution of this research is to highlight the potential for renewable energy in the Amazon region, showing the possibilities of meeting the diverse energy demands and offer renewable energy as a great solution in the form of hybrid systems to mitigate the use of diesel and reduce local energy problems. The sustainable propagation of energy in this region adds economic development to the local population. A consequence of this whole process is the improvement of quality of life. However, in the last few years, this population has faced unrestrained deforestation with higher $\mathrm{CO}_{2}$ emission rates. However, remote communities in the Amazon are mainly responsible for fighting for sustainable land development, access to energy, and the preservation of the forest with its flora and fauna.

\section{Autonomous Hybrid Energy Systems}

The definition of stand-alone hybrid energy systems is their operation off-grid $[5,6,27,28]$. Generation systems connected to the grid in Brazil present mandatory standards aiming at the proper security of the electricity distribution system and its users. Autonomous systems are also subject to requirements according to the country's normative resolution $N^{\circ} 493 / 2012$, which establishes the procedures and conditions for electricity supply through isolated energy generation and distribution systems or individual generation system of electricity with intermittent sources, also including hybrid systems resulting from the combination of two or more of the following primary sources: solar, wind, biomass, hydro, and diesel $[5,29,30]$.

Autonomous hybrid energy systems can be used with isolated topologies or mini-grids in low or high voltage, single-phase or three-phase. The demand for power and the load to be installed is what governs the system specifications. Low-voltage (single-phase) networks to supply a low-power point demand (using televisions, cell phone chargers, radios, and lighting) dominate isolated systems applications. In contrast, a high voltage/three-phase grid has its application reduced to systems with high power loads such as motors and pumps [31-33].

There are two main classifications of system operating topologies: alternating current (AC) and direct current (DC). In the case of the DC topology, the photovoltaic generator and the diesel generator share the function of charging the battery storage. The DC serial topology requires more electronic power resources that can reduce the overall efficiency of the system, as well as the viability of the system. In addition, this topology limits the control of the diesel generator [34,35].

In the parallel topology, the generators have a connection on the AC bus and the storage system (batteries) to the DC bus. The operation occurs with the PV generation system charging the batteries when necessary and feeding the loads simultaneously. The diesel generator in the system has a backup function. The implementation of this system is more complicated due to the operation in parallel, but the advantages provide more significant optimization and efficiency [36-39].

A third option is the application of mixed topologies, where all sources supply DC energy, which is then converted to $\mathrm{AC}$ by power electronics equipment. $\mathrm{PV}$ generators naturally produce electrical energy in DC. The AC energy supplied by the diesel generator is rectified to DC. This is the most used topology, which allows the supply of AC energy according to required voltage and frequency standards through DC-AC inverters [5,40].

\section{Methodology}

Currently, many software dominate the market and the scientific environment to assist in the dimensioning, optimization, and financial analysis of renewable and hybrid energy projects. Among the list of the most studied and used software in the literature are HOMER, Hybrid2, RETScreen, iHOGA, PVSyst, PV*Sol, INSEL, TRNSYS, iGRHYSO, HYBRIDS, RAPSIM, SOMES, SOLSTOR, HySim, HybSim, IPSYS, HySys, PVGIS, PVWatts, Solargis, ARES, SOLSIM, and HYBRID DESIGNER [41-49]. However, HOMER is the simulation tool chosen for the case study [27,50-65]. Amongst all software 
options, HOMER stands out in the field of hybrid systems because it allows the simultaneous simulation of a higher number of renewable and non-renewable generating sources in the same project. Another advantage is the integration with Matlab, which allows the insertion of new strategic energy dispatch controls.

Despite many advantages, HOMER has limitations such as not considering the depth of discharge (DOD) of the battery bank that affects the calculation of the useful life and the number of batteries used in the system. The software does not operate with busbar voltage variations. It also does not have the possibility of 3D simulations to study shading when using a photovoltaic energy source.

Lambert et al. [66] defines HOMER PRO (Hybrid Optimization of Multiple Energy Resources) as a computational model developed by the United States National Renewable Energy Laboratory (NREL). The software consists of three main tasks: simulation, optimization, and sensitivity analysis.

\subsection{Calculation of the Output Power of the Photovoltaic Array}

The nominal capacity of the photovoltaic generator is the amount of energy produced under standard irradiance test conditions of $1 \mathrm{~kW} / \mathrm{m}^{2}$ and module temperature of $25^{\circ} \mathrm{C}$.

The following equation models the calculation of the output power of the photovoltaic array, taking into account the effect of temperature.

$$
P_{P V}=Y_{P V} f_{P V} \frac{G_{T}}{G_{T, S T C}}\left[1+\alpha_{p}\left(T_{c}-T_{c, S T C}\right)\right]
$$

where, $Y_{P V}$ is the nominal capacity of the photovoltaic module under standard test conditions $(\mathrm{kW})$, $f_{P V}$ is the photovoltaic energy reduction factor $(\%), G_{T}$ is the solar radiation incident on the photovoltaic panel in real conditions $\left(\mathrm{kW} / \mathrm{m}^{2}\right), G_{T, S T C}$ is the incident irradiance under standard test conditions $\left(1 \mathrm{~kW} / \mathrm{m}^{2}\right), \alpha_{p}$ is the temperature coefficient of power $\left(\% /{ }^{\circ} \mathrm{C}\right), T_{c}$ is the photovoltaic cell temperature in real conditions $\left({ }^{\circ} \mathrm{C}\right), T_{C, S T C}$ is the photovoltaic cell temperature under standard test conditions $\left(25^{\circ} \mathrm{C}\right)$.

\subsection{KiBaM Battery Model}

HOMER incorporates in its simulations the battery model of Manwell, and McGowan [67], who developed an empirical model of lead-acid battery for application in hybrid energy systems, known as Kinetic Battery Model (KiBaM) [68,69].

The KiBaM model presents the battery charge distribution divided into two tanks: one is responsible for the charge available to be transformed into DC electricity, and the other corresponds to the limited charge (a chemical charge that is not yet available for consumption).

The KiBaM model (Figure 1) shows that each part has a different height, width, and volume. A fraction $c$ of the total capacity represents the available load $\left(y_{1}\right)$ and the fraction $1-c$ is the limited load $\left(y_{2}\right)$. The process occurs with the available charge providing electrons for the load I, while the limited load provides electrons through the $k$ valve for the available load. 


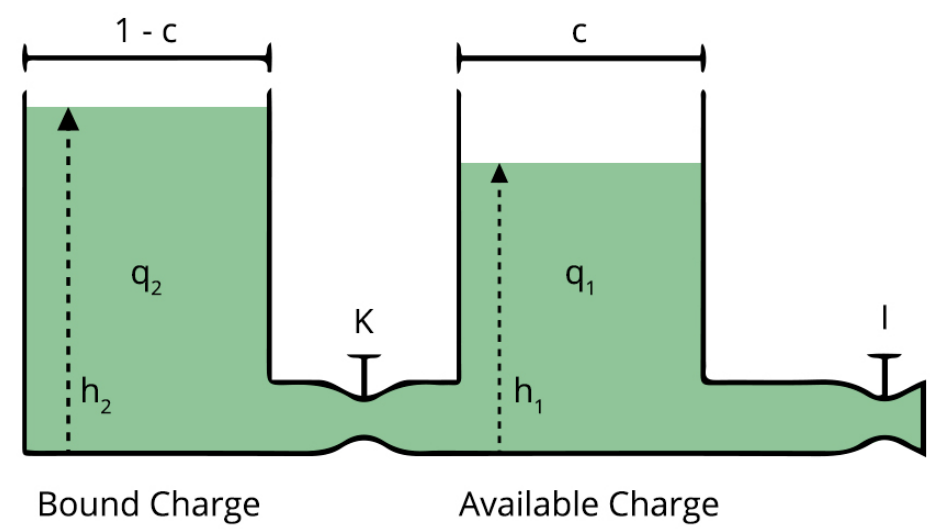

Figure 1. KiBaM battery model [67]. Reprinted from [67] with permission (License 4844200377381) from Elsevier.

HOMER calculates the life of the battery bank in years, from:

$$
R_{b a t}=\min \left(\frac{N_{b a t t} Q_{\text {liftime }}}{Q_{t t a}}, R_{b a t t, f}\right)
$$

where $N_{\text {batt }}$ is the number of batteries, $Q_{\text {liftime }}$ the life rate of a single battery, $Q_{t t a}$ the annual transfer rate (the total amount of energy that travels through the bank of batteries in a year) and $R_{b a t t, f}$ is the battery life (the maximum life, regardless of performance).

\subsection{Diesel Generator Set}

The sizing of the diesel generator set considers the complete supply of the need for peak load demand and powering the storage [66]. The main physical properties of the generator are its maximum and minimum electrical power, its expected life in hours of operation, the type of fuel it consumes, and its fuel curve, which relates the amount of fuel consumed to the electrical energy produced. Its characterization is given through fuel consumption in $\mathrm{L} / \mathrm{h}$ or specific consumption in $\mathrm{L} / \mathrm{kWh}$ to meet the particular load demand [70-72].

The fuel consumption of the diesel generator is described as a straight line with a $y$-intercept and can be calculated from the equation:

$$
C C_{D G}=a_{0} P_{D G}+b_{0} P N_{D G}
$$

where, $P_{D G}$ is the nominal capacity $(\mathrm{kW})$ and $P N_{D G}$ the electrical output of the diesel generator $(\mathrm{kW})$, respectively. The coefficients $a_{0}$ and $b_{0}$ are the intercept of the fuel curve which is the unladen fuel consumption of the generator divided by its nominal capacity and the slope of the fuel curve representing the marginal fuel consumption the generator. The results are expressed in $\mathrm{L} / \mathrm{kWh}$.

\section{Case Study}

\subsection{Locality Characterization}

The Tapajós-Arapiuns Extractive Reserve is a territory of almost 650 thousand hectares, in the state of Pará within the Amazon region with the geographical coordinates $02^{\circ} 20^{\prime}$ to $03^{\circ} 40^{\prime}$ South, and $55^{\circ} 00^{\prime}$ to $56^{\circ} 00^{\prime}$ West (Figure 2). It is the most populous reserve in Brazil, with about 22 thousand inhabitants distributed in 74 communities, most of whom are traditional low-income and vulnerable agricultural groups. Access to the reserve is made by boat through the Tapajós and Arapiuns rivers. 


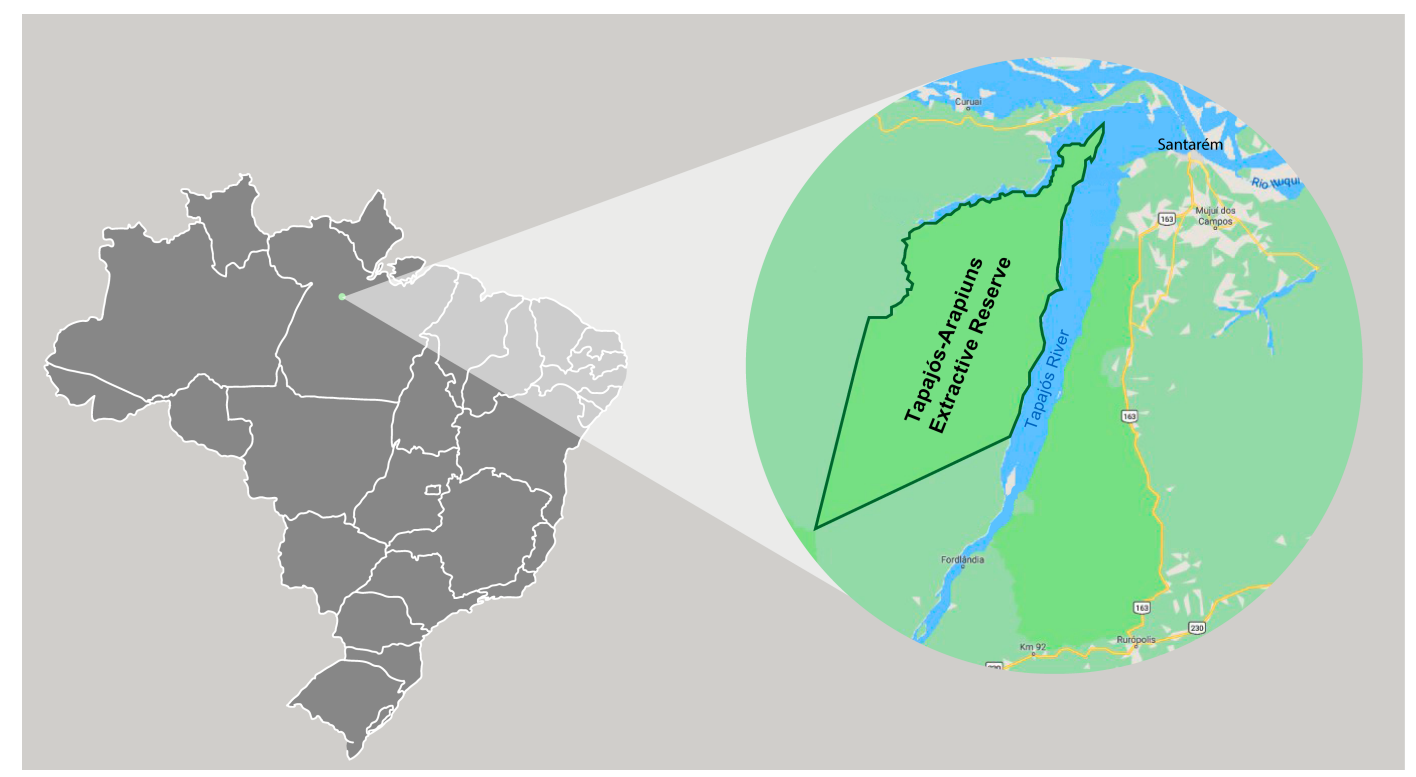

Figure 2. Location of the Tapajós-Arapiuns Extractive Reserve in the state of Pará.

In the strategic area of the region, close to the Tapajós and Arapiuns rivers, a non governmental organization called the Center of Advanced Social and Environmental Studies (CEAPS) has created a reference pole called "Active Forest" Experimental Center (CEFA). CEFA is a reference pole for training and developing social and environmental projects and technologies replicable to the entire forest. It is a place for seminars, training, and workshops for the local population. Sustainable development at the site brings together the main productive elements in a single integrated field system (nurseries, vegetable gardens, aquaculture, meliponiculture, among other activities). CEFA also hosts experimental renewable energy systems to study the feasibility of applying these systems in the region to foster public policies aimed at the energy development of isolated communities without access to the conventional electrical system.

\subsection{Load Profile}

Determining the typical load curve of a place with such climatic seasonality presents certain obstacles, as these variations directly influence the local habits of electricity consumption $[33,73,74]$.

CEFA is a place with considerable variation in energy consumption and there is a high degree of complexity to accurately estimate its average annual load profile. After estimating the annual use of the loads in 2017, five different consumption profiles (Figure 3) were found that appear at certain times of the year, and that drastically affect the use of each HES generation component. 

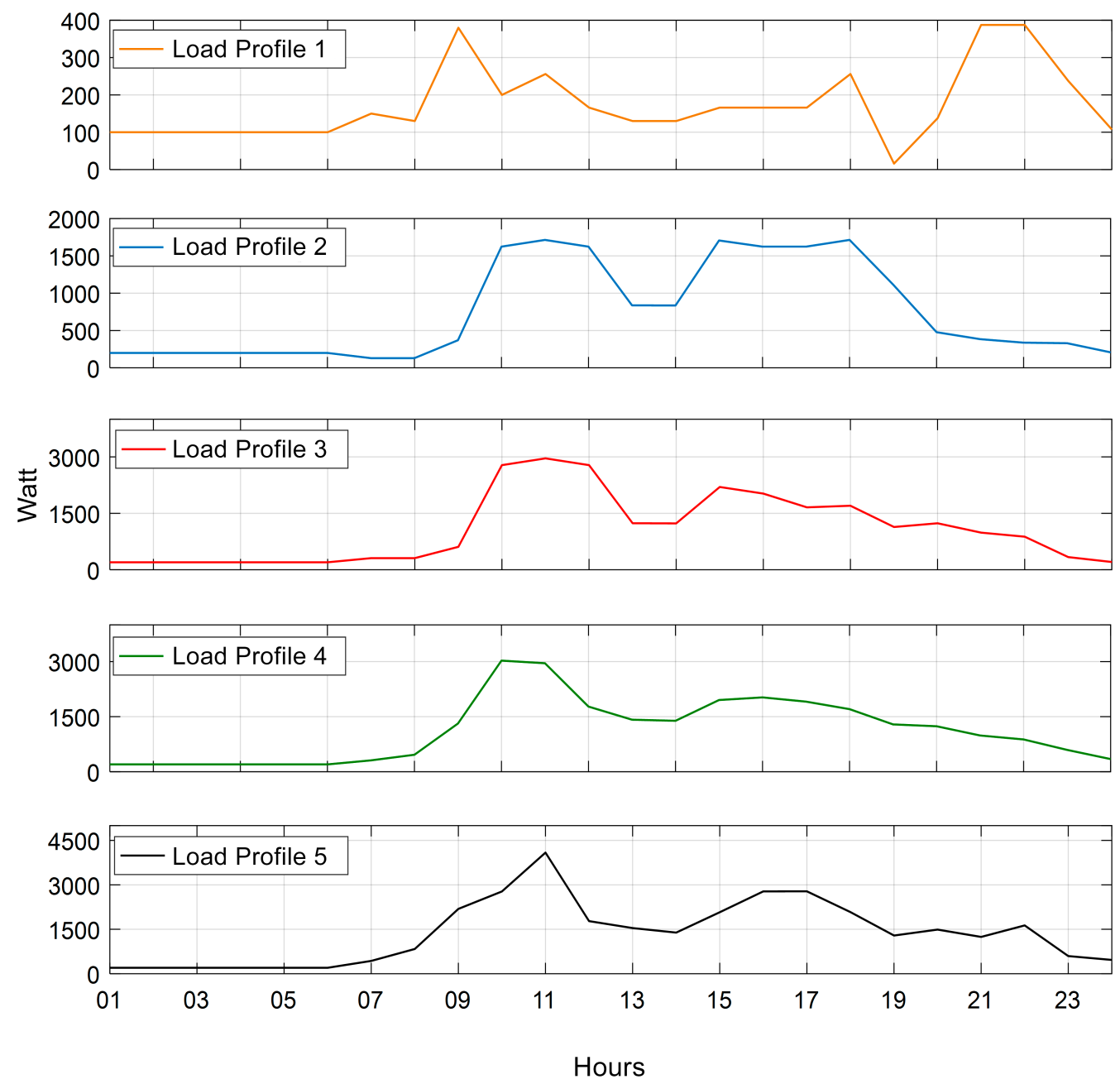

Figure 3. Load profiles in different days of the year.

Realistically, the size and shape of the load profile vary from one day to another. We obtained five load profiles based on the consumption information of past years. With these data HOMER was used to plot random daily synthetic profiles with variability of $80.136 \%$, with a constant consumption peak. The profiles retained the same shape for each day, but were scaled up or down. Thus, daily consumption was $6.16 \mathrm{kWh}$ with a peak demand of $4.08 \mathrm{~kW}$, with July having the highest peak demand.

\subsection{Solar Energy Potential}

The local radiation data taken from the NASA SSE base showed the annual average daily radiation was $4.96 \mathrm{kWh} / \mathrm{m}^{2} /$ day (Figure 4). March and May were the months of less radiation $\left(4.37 \mathrm{kWh} / \mathrm{m}^{2} /\right.$ day) because of the rainy periods in the region and September had the highest daily radiation of $5.93 \mathrm{kWh} / \mathrm{m}^{2} /$ day. 


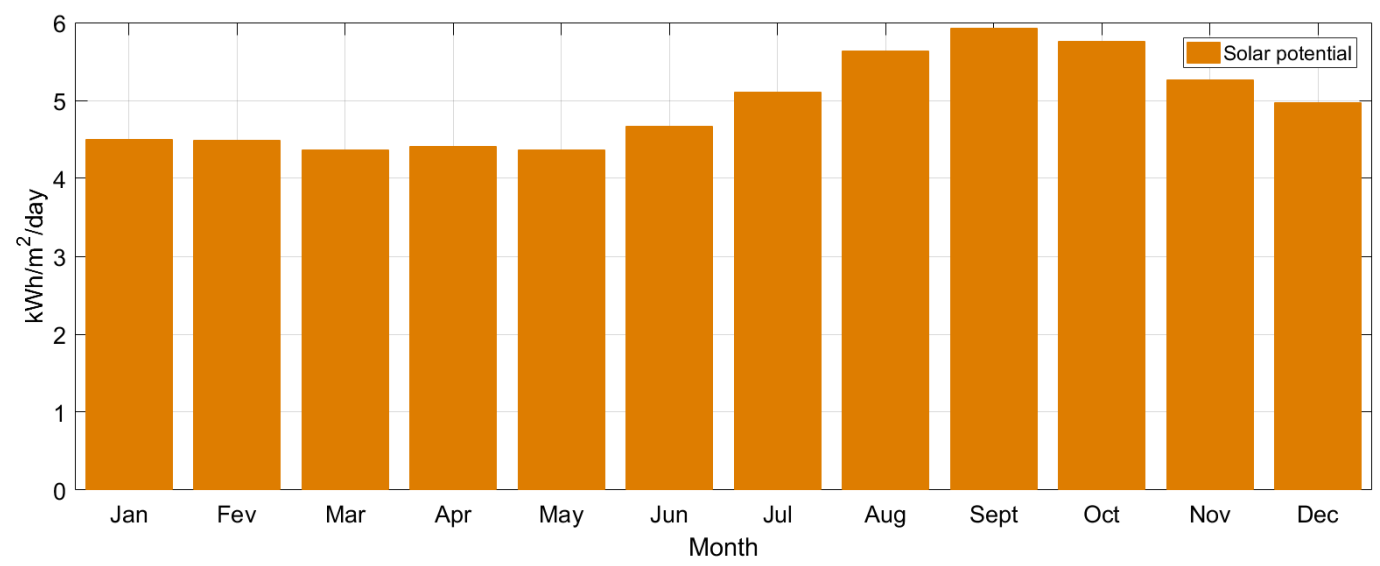

Figure 4. Solar potential in the Tapajós-Arapiuns Extractive Reserve.

\subsection{Assessment of Wind Energy Potential}

Wind farms in Brazil behave differently according to geographic regions. The territory of the Tapajós-Arapiuns Extractive Reserve (Resex) occupies part of the Eastern Amazon Basin region. The Eastern Amazon portion extends around the city of Santarém approximately $100 \mathrm{~km}$ from the coast between Amapá and Maranhão. In this region, the tropical depression is part of the relief at low altitudes (in some locations below sea level). Light winds mold the wind profile in the central depression area.

The wind potential in this region of the Amazon is weak, with an annual wind average of less than $3.5 \mathrm{~m} / \mathrm{s}$. In the area of Resex, this value is rarely exceeded during the year, occurring between the end of July and the beginning of October. The average annual wind speed at CEFA is approximately $1.87 \mathrm{~m} / \mathrm{s}$. This low energy potential is due to the location and the high surface friction caused by the dense vegetation's roughness.

The analysis of the wind potential so that it has a technically usable result must present the result of a power density greater than or equal to $500 \mathrm{~W} / \mathrm{m}^{2}\left(E_{m}\right)$, at a standard height of $50 \mathrm{~m}$ above the ground, which requires a minimum wind speed of 7 to $8 \mathrm{~m} / \mathrm{s}\left(V_{m}\right)$ [75].

By observing the wind data from Resex, the likelihood of success at a wind farm in this location is extremely low. Comparing the CEFA wind data with classes defined in Table 1, the result is the classification in class $1(\mathrm{Vm}>3 \mathrm{~m} / \mathrm{s})$, proving the inviability of the wind project.

The HES initially had a $500 \mathrm{~W}$ wind turbine with 24 VDC output (18 A), connected to the DC link in parallel with the photovoltaic system for charging the battery bank. Although the wind turbine was part of the hybrid system, the wind potential in the region was scarce, as demonstrated in this topic.

HOMER simulations of the original HES corroborate the infeasibility of wind energy in this place. To reach the total power of $500 \mathrm{~W}$ of the wind turbine, the wind speed must be in the range of 15 to $16 \mathrm{~m} / \mathrm{s}$, being a wind regime that did not occur on this site.

The contribution of wind energy to the HES energy supply was approximately $1 \%$ of the total. Figure 5 shows the output power of generators and the load power during a certain time interval, in which the power of the wind turbine was negligible.

Table 1. Definition of wind energy classes. In class 1 the probability of success in the installations is extremely low. Class 4 occurs in environments with greatest wind potential. Classes 2 and 3 have intermediary energy potentials. Source: Adapted from Feitosa [76].

\begin{tabular}{ccccccccccc}
\hline & \multicolumn{2}{c}{ Thicket } & \multicolumn{2}{c}{ Open Field } & \multicolumn{2}{c}{ Coastal Area } & \multicolumn{2}{c}{ Hill } & \multicolumn{2}{c}{ Mountain } \\
\hline Class & $V_{\boldsymbol{m}}(\mathbf{m} / \mathbf{s})$ & $E_{\boldsymbol{m}}\left(\mathbf{W} / \mathbf{m}^{2}\right)$ & $V_{\boldsymbol{m}}(\mathrm{m} / \mathbf{s})$ & $\mathbf{E}_{m}\left(\mathbf{W} / \mathbf{m}^{2}\right)$ & $V_{m}(\mathbf{m} / \mathbf{s})$ & $E_{m}\left(\mathbf{W} / \mathbf{m}^{2}\right)$ & $V_{m}(\mathbf{m} / \mathbf{s})$ & $E_{m}\left(\mathbf{W} / \mathbf{m}^{2}\right)$ & $V_{m}(\mathbf{m} / \mathbf{s})$ & $E_{m}\left(\mathbf{W} / \mathbf{m}^{2}\right)$ \\
\hline $\mathbf{4}$ & $>6$ & $>200$ & $>7$ & $>300$ & $>8$ & $>480$ & $>9$ & $>700$ & $>11$ & $>1250$ \\
3 & $4.5-6$ & $80-200$ & $6-7$ & $200-300$ & $6.5-8$ & $250-480$ & $7.5-9$ & $380-700$ & $8.5-11$ & $650-1250$ \\
$\mathbf{2}$ & $3-4.5$ & $25-80$ & $4.5-6$ & $80-200$ & $5-6.5$ & $100-250$ & $6-7.5$ & $200-380$ & $7-8.5$ & $300-650$ \\
$\mathbf{1}$ & $<3$ & $<25$ & $<4.5$ & $<80$ & $<5$ & $<100$ & $<6$ & $<200$ & $<7$ & $<300$ \\
\hline
\end{tabular}




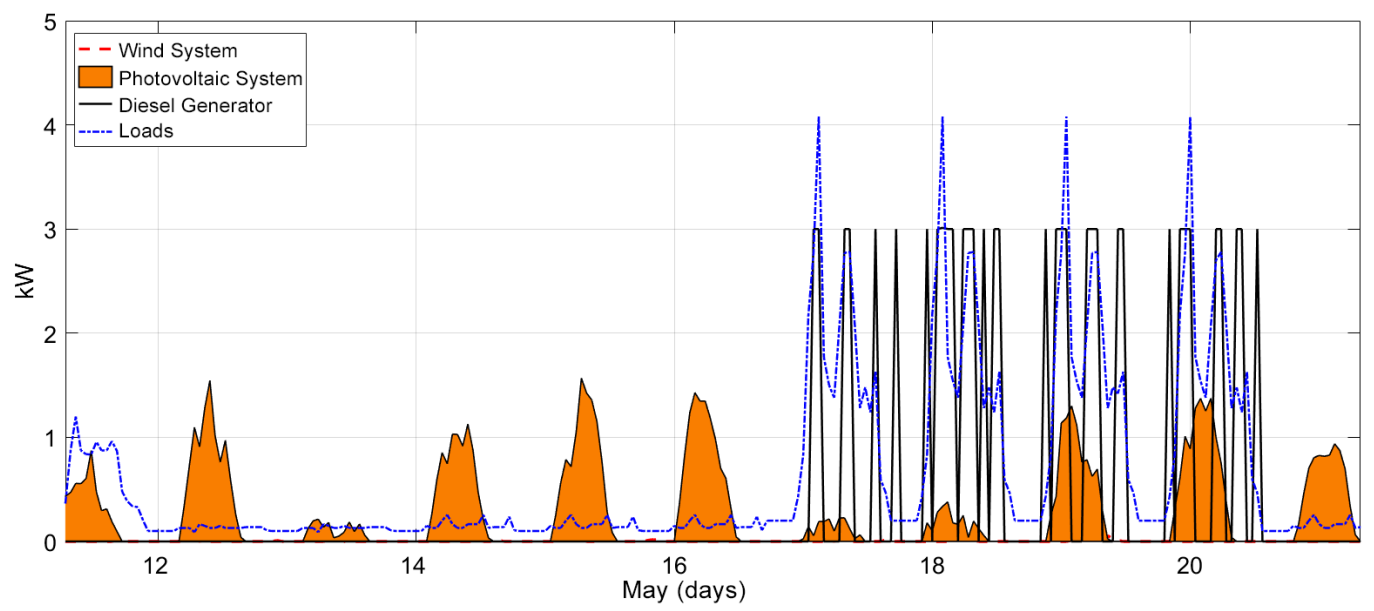

Figure 5. Output power from power sources and system loads between 12 to 20 May.

\subsection{PV-Diesel System Description}

The CEFA has a highly variable energy demand throughout the year. The photovoltaic-diesel hybrid system (Figure 6) feeds part of the loads such as electronics. In the local there are other photovoltaic systems to meet specific cooling and lighting loads.

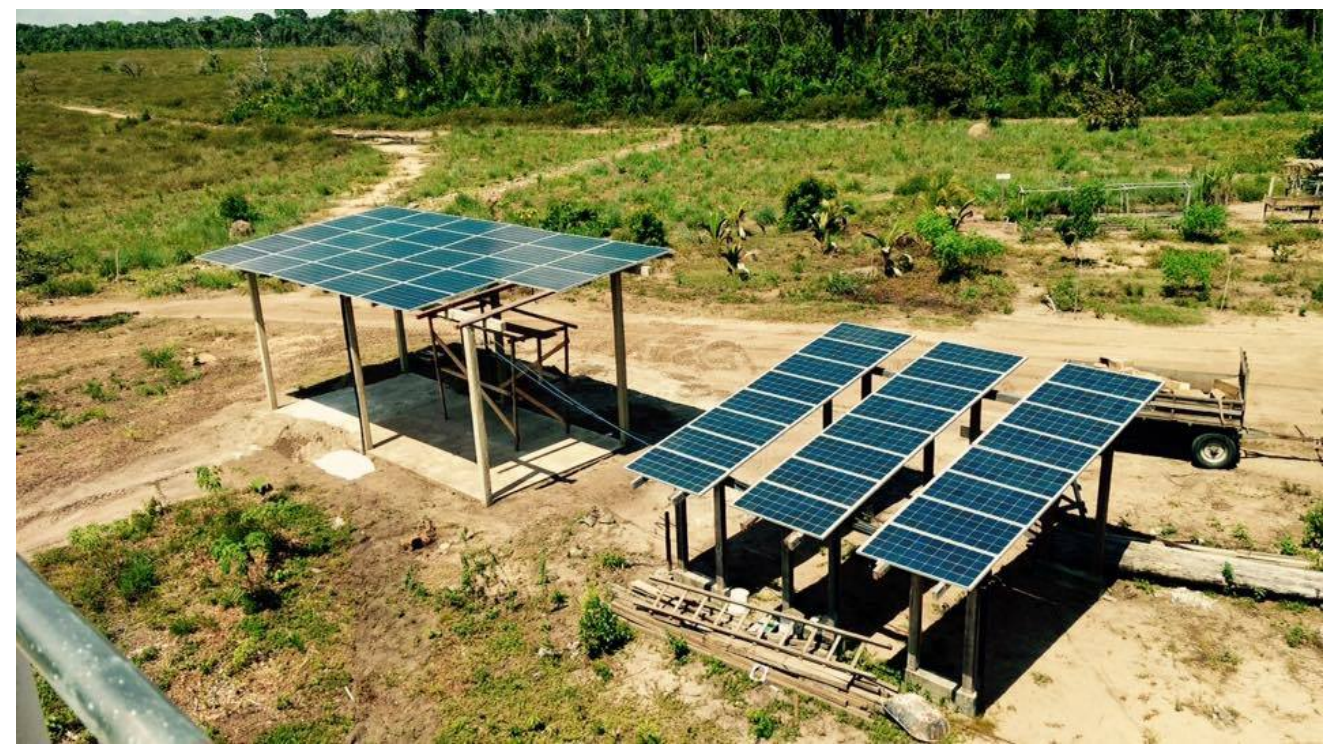

Figure 6. Installation of modules added to the hybrid system.

The presented system supplied AC loads in a 127 VAC grid. On the DC side there was a $2.1 \mathrm{kWp}$ PV generator with an array formed by strings of two modules connected in series and several paralleled strings. The charge controller performed the energy management of the panels with a 1100 Ah battery bank. The AC power was provided by an inverter of $1800 \mathrm{~W} / 24$ VDC-120 VAC (technical specifications in Table 2) and a diesel generator set to $12 \mathrm{kVA}$. 
Table 2. Technical specifications of the Xantrex PROsine $1800 \mathrm{~W}$ inverter.

\begin{tabular}{lc}
\hline \multicolumn{2}{c}{ Model Xantrex PROsine } \\
\hline Output power & $1800 \mathrm{~W}$ \\
Outbreak classification & $2900 \mathrm{~W}$ \\
Output current (peak) & $45 \mathrm{~A}$ \\
Output voltage (AC) & $120 \mathrm{~V}$ \\
Output frequency & $60 \mathrm{~Hz}$ \\
\hline
\end{tabular}

The photovoltaic system had a power of $2.1 \mathrm{~kW}$ composed of four sets containing modules of $260 \mathrm{~W}$ and $265 \mathrm{~W}$. The first two strings were composed of four photovoltaic panels of $265 \mathrm{~W}$, with two modules associated in series and connected to charge controllers with a 24 VDC input. The $260 \mathrm{~W}$ modules had the same configuration as before and the load controllers were connected in parallel to connect to the inverter outside the grid (Figure 7).

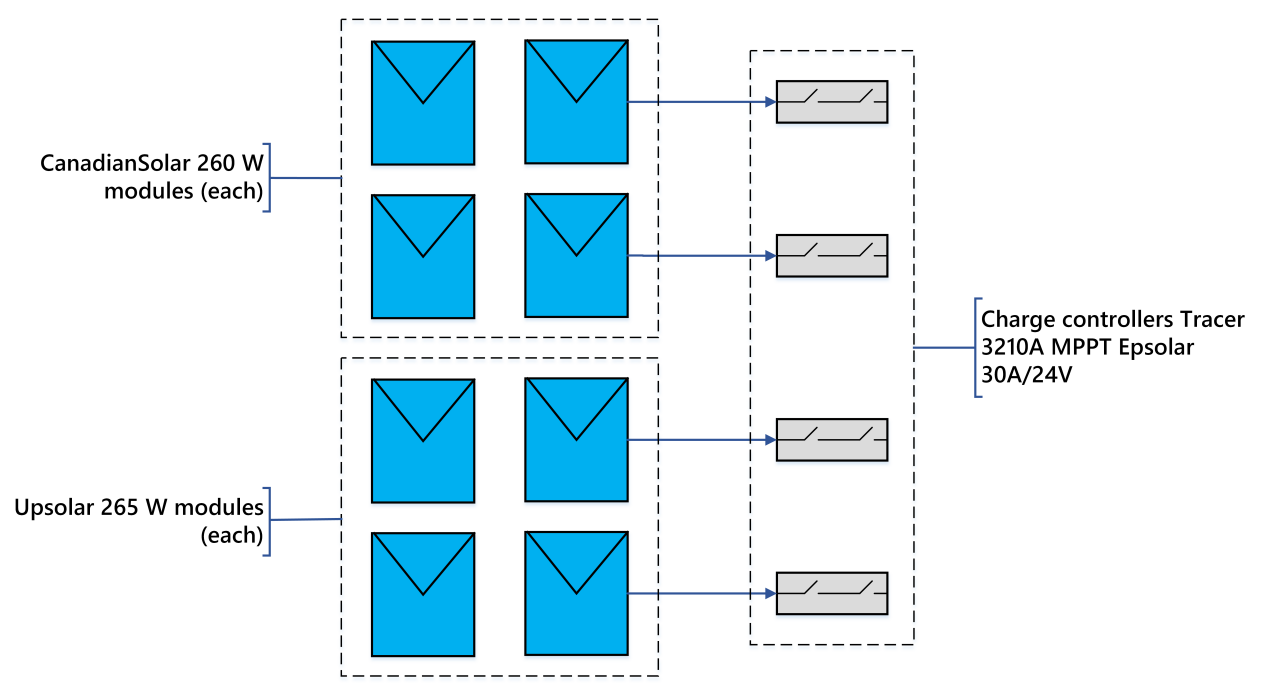

Figure 7. Arrangement of photovoltaic modules and their connections.

Table 3 contains the technical specifications of each solar panel model that are used in the hybrid energy system.

Table 3. Technical specification of photovoltaic modules.

\begin{tabular}{lcc}
\hline & UP-M265P & CS6P-260 \\
\hline Manufacturer & Upsolar & CanadianSolar \\
Nominal Max. Power (Pm) & $256 \mathrm{~W}$ & $260 \mathrm{~W}$ \\
Opt. Operating Voltage (Vmp) & $31.6 \mathrm{~V}$ & $30.4 \mathrm{~V}$ \\
Opt. Operating Current (Imp) & $8.40 \mathrm{~A}$ & $8.56 \mathrm{~A}$ \\
Open Circuit Voltage (Voc) & $38.8 \mathrm{~V}$ & $37.5 \mathrm{~V}$ \\
Short Circuit Current (Isc) & $8.70 \mathrm{~A}$ & $9.12 \mathrm{~A}$ \\
Module Efficiency & $16.3 \%$ & $16.16 \%$ \\
\hline
\end{tabular}

The diesel generator set installed in the hybrid system had a Yanmar series YT22E stationary diesel engine, with a continuous output power of $16.2 \mathrm{HP} / 1800 \mathrm{RPM}(11.9 \mathrm{~kW})$ and intermittent output power $18 \mathrm{HP} / 1800 \mathrm{RPM}(13.2 \mathrm{~kW})$. This was a single-cylinder and four strokes engine, with direct injection and cooling system with a water tank. The starting system was manual, and the engine could support a $15 \mathrm{~L}$ fuel tank with consumption of $175 \mathrm{~g} / \mathrm{HPh}(126.5 \mathrm{~g} / \mathrm{kWh})$. The generator was a $12.5 \mathrm{kVA}$ Bambozzi synchronous alternator with $10 \mathrm{~kW}$ continuous generated power, four poles and $60 \mathrm{~Hz}-380 / 220$ VAC output. The output voltage could be adjusted in a range of $\pm 15 \%$ of the nominal voltage, in addition to operating at $1800 \mathrm{RPM}$ and $16.8 \mathrm{HP}$ traction power. 
The battery bank had 10 stationary 220 Ah lead-acid batteries. Each battery had a nominal voltage of $12 \mathrm{~V}$, a standard temperature of $25^{\circ} \mathrm{C}$, and fluctuation voltage in the range of $13.2 \mathrm{~V}$ to $13.38 \mathrm{~V}$. The system had a configuration of two batteries in series, providing a nominal voltage of $24 \mathrm{~V}$ and a total capacity of $1100 \mathrm{Ah}$ and $26.40 \mathrm{kWh}$. However, of this capacity, only $21.12 \mathrm{kWh}$ could be used, taking into account the state of charge (SOC) of $80 \%$. The number of cycles for these batteries ranges from 1095 to 10,300 , considering that the discharges were close to $80 \%$.

The power conditioning system has controllers for solar and wind loads, protection boxes (DC and AC), inverter, and manual switching (Figure 8). These components operate by controlling the power flow between power generators and loads, as well as converting directly to alternating current. The system was configured for a 24 VDC nominal voltage. Therefore, all equipment followed this parameter.

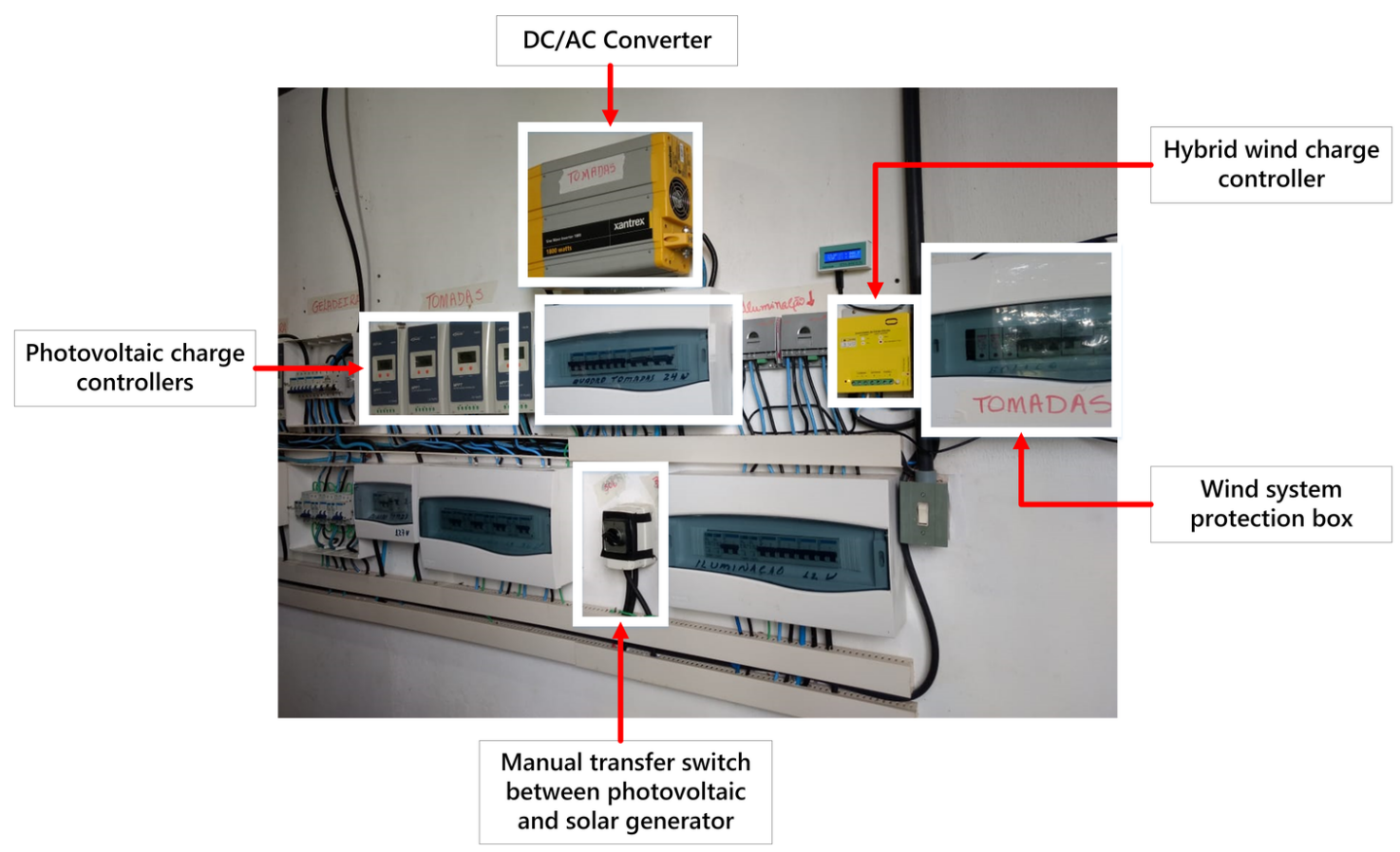

Figure 8. Components of the power conditioning system.

The transfer switch was like a switch between the loads and the two sources. If there was a power interruption by the photovoltaic generator at any time, the transfer switch activated the diesel so that it operated while the PV system resumed operation. This type of transition manually caused some human failure, such as detecting the ideal time to turn on each energy source.

\section{Results and Discussion}

From the technical infeasibility of the wind system, the analyses continued to consider only the sources with the best performance and the most significant assistance in meeting the loads. The reduced HES, now limited to a photovoltaic-diesel combination, remained capable of responding for $100 \%$ of the service to loads, in addition to reducing system losses and excess energy production. Thus, this session presents the results of the performance of this system based only on PV and diesel as energy sources.

HOMER was fed with input data to perform different configurations of the sources and combinations of the components. The result appeared through a list of the best systems. The system's input data were the specifications of a $10 \mathrm{~kW}$ diesel generator, 260/265 Wp solar panels, and 220 Ah batteries.

Figure 9 shows the configuration adopted for the system, the mixed topology (series/parallel) with the generator set on the side installed on the AC bus for backup, minimizing the consumption of non-renewable fuels. 


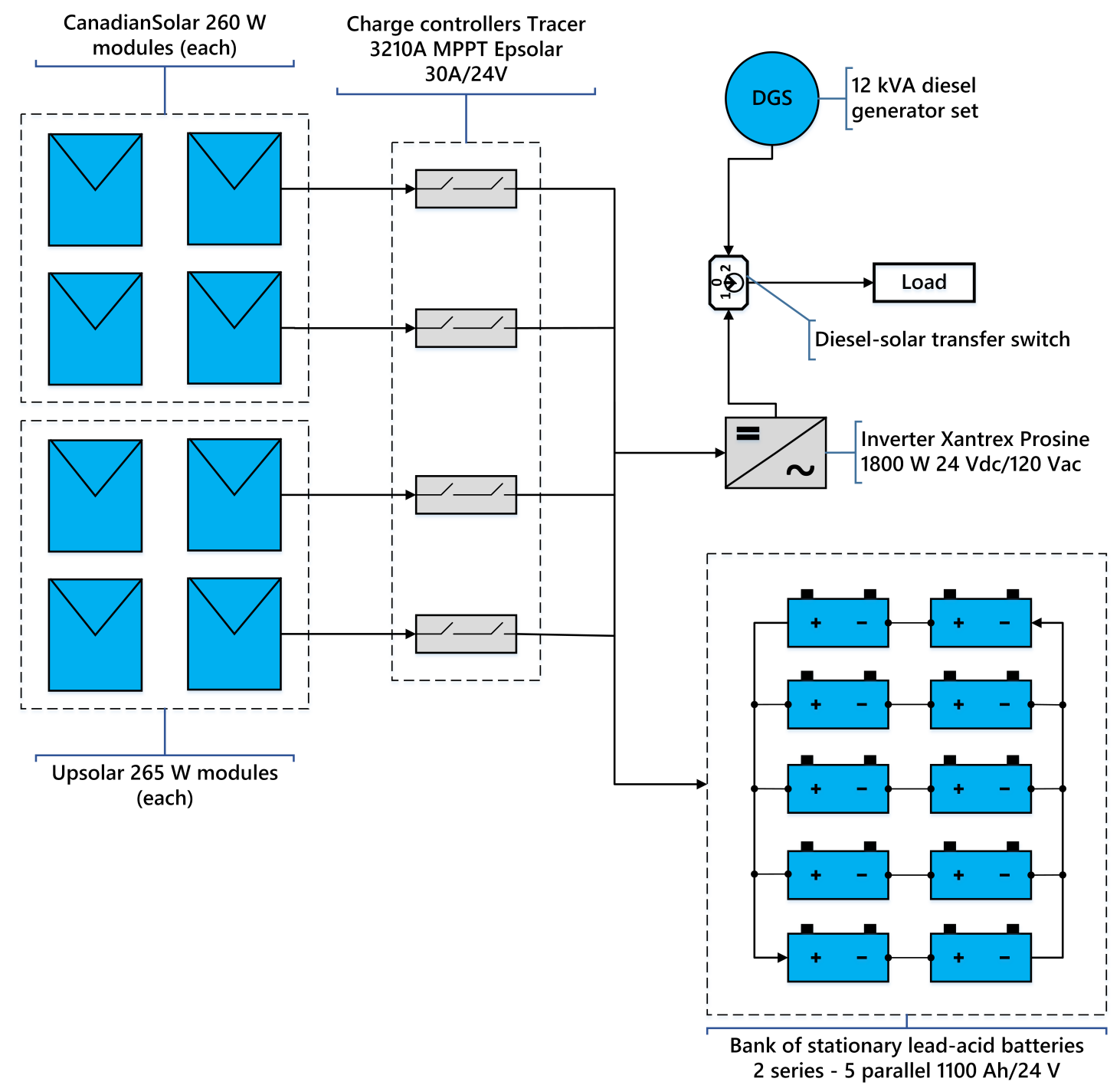

Figure 9. Mixed topology (series/parallel) adopted in hybrid energy systems (HESs).

\subsection{Analysis of the Daily Variation of the Minimum Load Profile}

For much of the year, energy consumption was low, characterized by a daily power of $3.53 \mathrm{~kW}$. This same demand varied throughout the year and increased by up to $\pm 10 \%$ in everyday life without variation in the peak load of $660 \mathrm{~W}$. Furthermore, for the optimization of the hybrid system, ideally, the photovoltaic system should meet the demand with a variation of up to $\pm 30 \%$. The use of the diesel generator in these conditions was not efficient, as it was on an empty work regime without operating at full power and with increased fuel consumption.

An analysis of the functioning and performance was carried out based on the daily variation of the minimum load profile of the hybrid photovoltaic-diesel system.

A variability of $10 \%$ in the load profile was added in the simulations because, in real cases, the loads did not behave steadily every day. Based on this information, HOMER changed the load profile for each day at a random value, maintaining the same peak demand. Figure 10 shows a month of the year with the load profile with and without variability. 

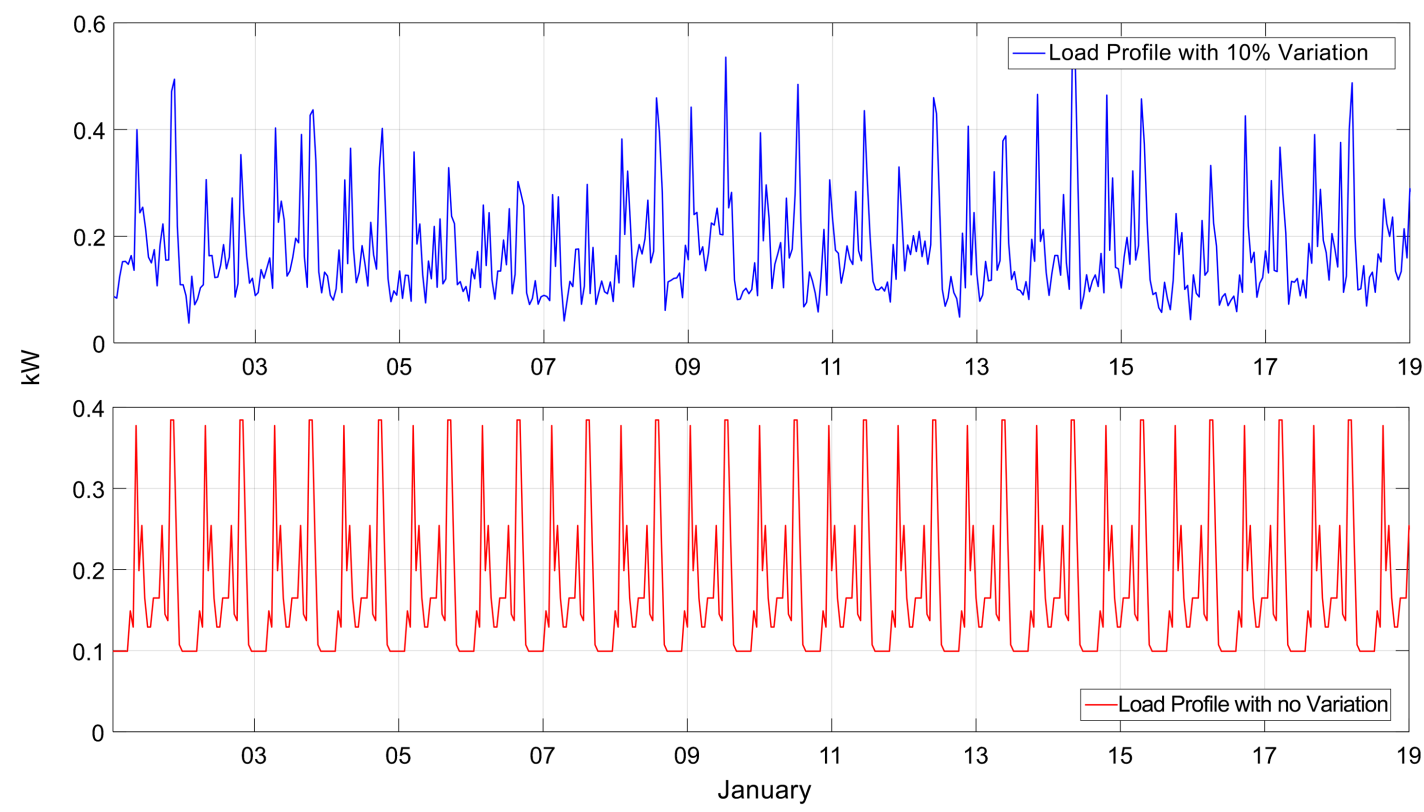

Figure 10. January load profile showing $10 \%$ variability in consumption.

The results of the variation of $10 \%$ showed the system produced $99.9 \%$ of the PV generation, and $0.0840 \%$ by the diesel generator.

The maximum annual photovoltaic production was $2973 \mathrm{kWh} /$ year, and diesel was started only once in this simulation for about $3 \mathrm{~h}$ with a production of $2.50 \mathrm{kWh} /$ year and consumption of $1.20 \mathrm{~L} /$ day of fuel (Figure 11). This isolated event occurred in the morning between 7:00 a.m. and 9:00 a.m. when the charge was high, the batteries reached the minimum charge state, and PV production was starting.

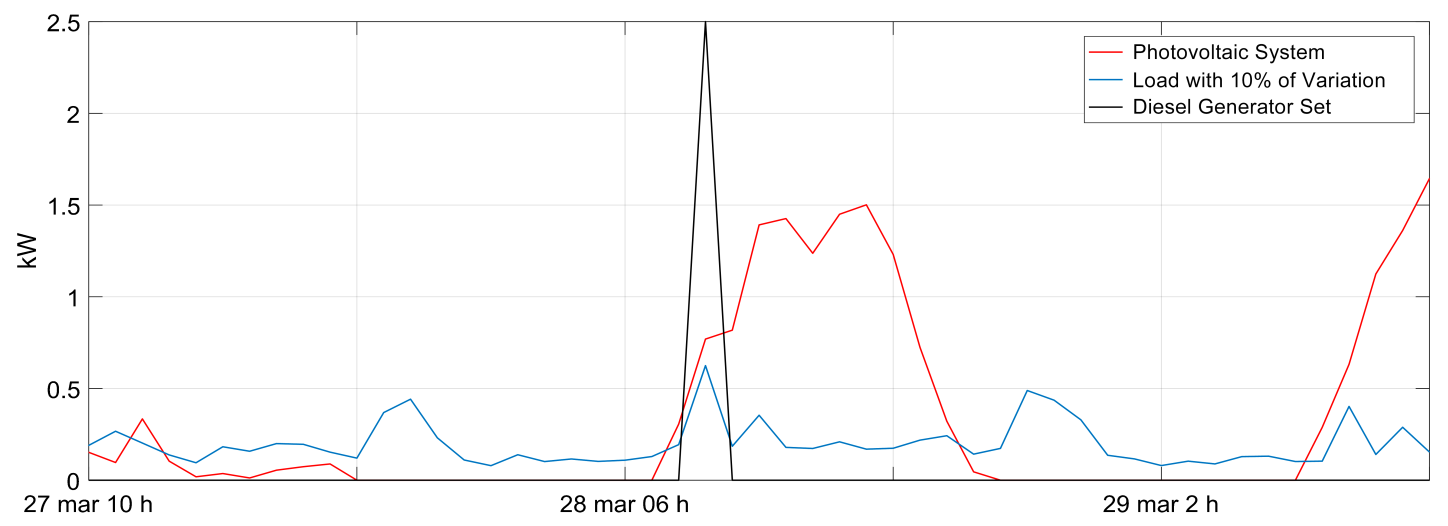

Figure 11. Behavior of the photovoltaic-diesel HES when there is low photovoltaic (PV) production with the activation of the diesel generator set.

The storage system allowed a minimum charge state of $40 \%$, for higher battery life and less replacements, operating at $24 \mathrm{VDC}$. The results show that the battery bank received $1067 \mathrm{kWh}$ of energy annually, having losses of approximately $214 \mathrm{kWh} /$ year. The state of charge of the battery bank for different days of the year and the blue region showed the highest consumption of stored energy in March and the lowest in July.

The photovoltaic system produced $1125 \mathrm{kWh}$ /year of energy in addition to the minimum load needs. It could supply a variation of up to $50 \%$ overnight without the need to start the diesel generator. When the load variation option was triggered, the profile changed without affecting its size. 
Access to the power system usually caused demand to rise over time. Climatic variation also changed consumption. The communities of Tapajós-Arapiuns Reserve used the place, and the number of people was unstable, causing a more significant variation of the daily load profile. After that, the simulation gained variation of the load profile by $50 \%$ randomly during the days, maintaining the minimum daily consumption of $4.27 \mathrm{kWh}$. However, higher demand peaks of up to $1.25 \mathrm{~kW}$ occurred.

\subsection{Energy System Analysis with Diesel Generator Set}

Generally, isolated locations are supplied only by diesel generators, which causes significant losses, gas emissions, and high fuel costs. Besides, diesel transportation is highly dangerous due to the risk of soil and effluent contamination.

Without using renewable energy systems, this facility would be supplied only by diesel generators, which is a widespread routine for electricity supply in isolated areas. Thus, the simulations aim to verify and analyze from the equipment installed in CEFA's hybrid energy system concerning the load supply, the use of the generator set, and the failures that may occur.

After simulating the system, it is possible to see the relationship between diesel and loads when they need a power supply. Figure 12 shows that the diesel generator operated with a minimum output power of $2.5 \mathrm{~kW}$ even when the load needs was below $0.5 \mathrm{kWh}$. As a consequence, the system produced $89.9 \%$ of excess electricity. That is, the consumption of loads was $2247 \mathrm{kWh}$ annually, and the diesel generator produced approximately $20,039 \mathrm{kWh} /$ year.

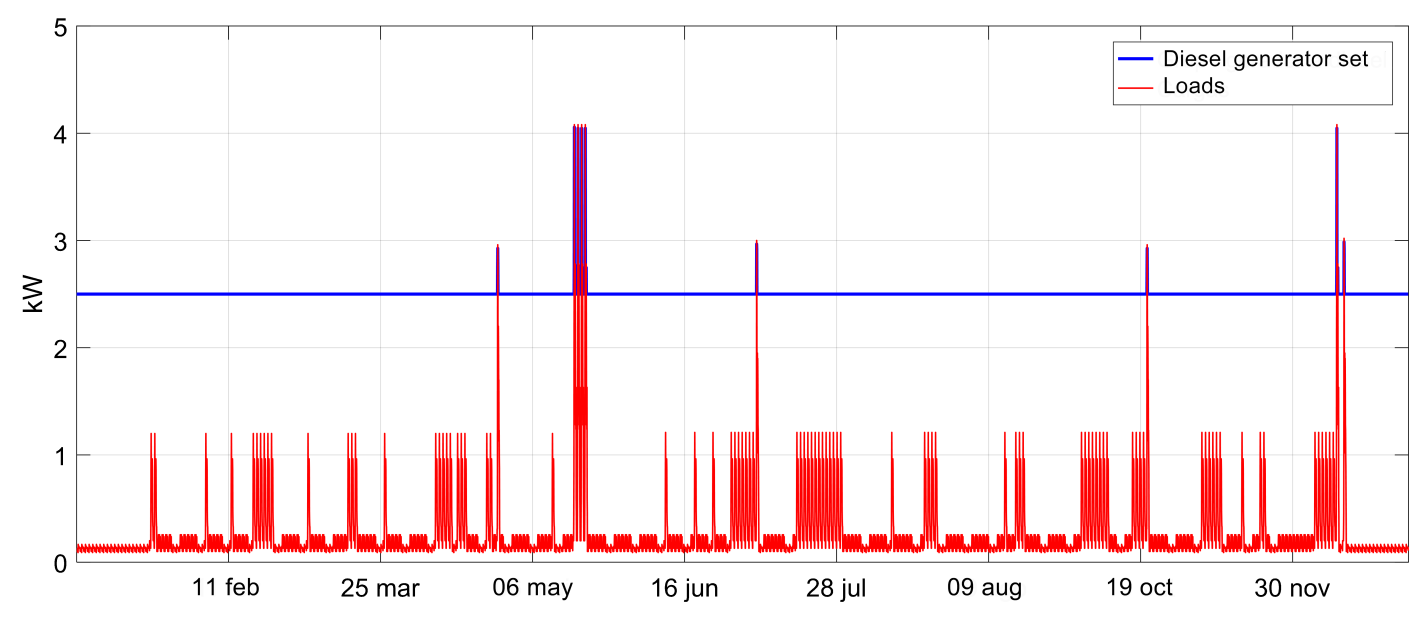

Figure 12. System powered only by diesel to feed the loads.

\subsection{Hybrid Photovoltaic-Diesel System}

The results obtained show that the hybrid system provided $85.6 \%$ of photovoltaic energy and $14.4 \%$ of the diesel generator, showing that the system is feasible and that the use of diesel was necessary only in times of peak consumption. The PV system produced an average of $8.15 \mathrm{kWh} /$ day and generates $2973 \mathrm{kWh} /$ year.

For better conservation of the battery bank, the minimum charge state of the batteries was $40 \%$. This choice occurred through the result of sensitivity analysis for $\mathrm{SOC}_{\min }$ of $40 \%, 50 \%$, and $60 \%$. When the batteries reach $\mathrm{SOC}_{\min }$ and the photovoltaic system was not established to supply the battery bank, the diesel generator was activated. The state of charge throughout the year is shown in Figure 13. 


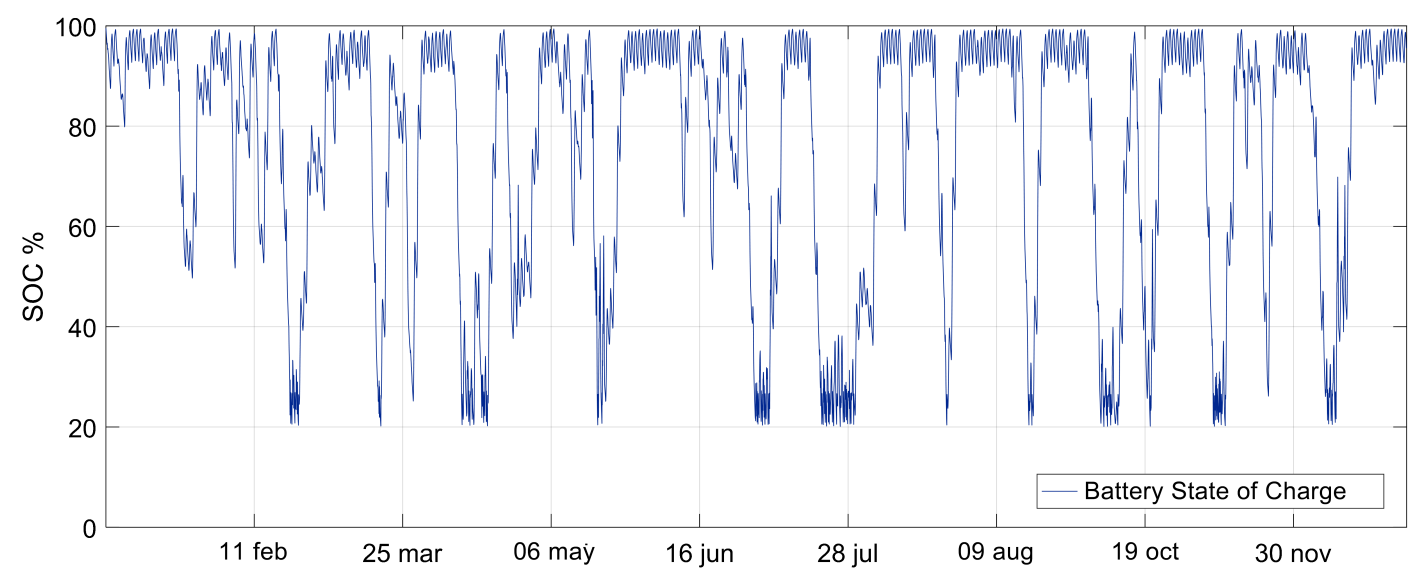

Figure 13. Battery bank annual state of charge (SOC).

The batteries could have up to $63.5 \mathrm{~h}$ of autonomy, depending on the predominant charge profile in a given period. The system received $1310 \mathrm{kWh} /$ year and had losses of $262 \mathrm{kWh} /$ year. The battery bank was used $55.77 \%$ of the time, the state of charge fluctuated $85.65 \%$ of the time, and SOC reached approximately $40 \%$ only $2.75 \%$ of the time used by the batteries (Figure 14 ).

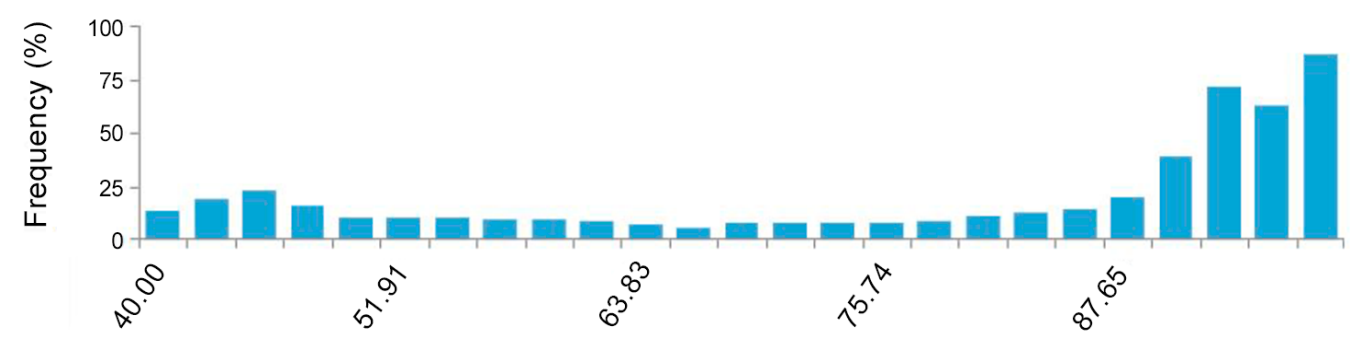

Figure 14. Frequency of SOC throughout the year.

The charging and discharging of the battery bank seen in Figure 15, presents the moments of low energy that occurred when there was no PV production, and the battery was in maximum discharge mode. When this situation occurs, the diesel generator started to supply the AC system, and DC was disconnected until its production stabilized (Figure 16).

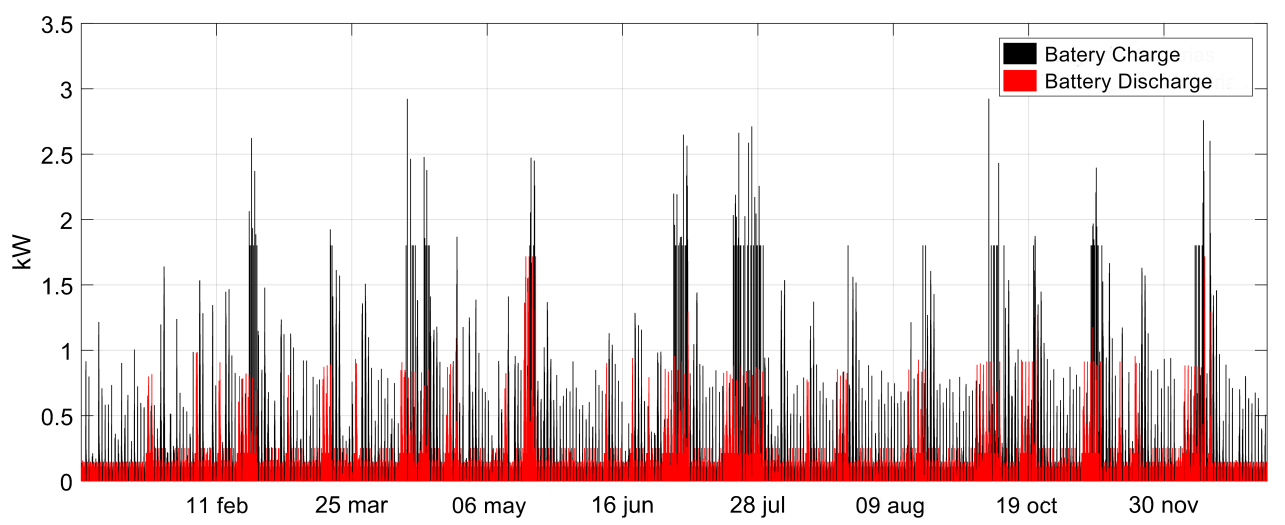

Figure 15. Battery bank charging and discharging. 

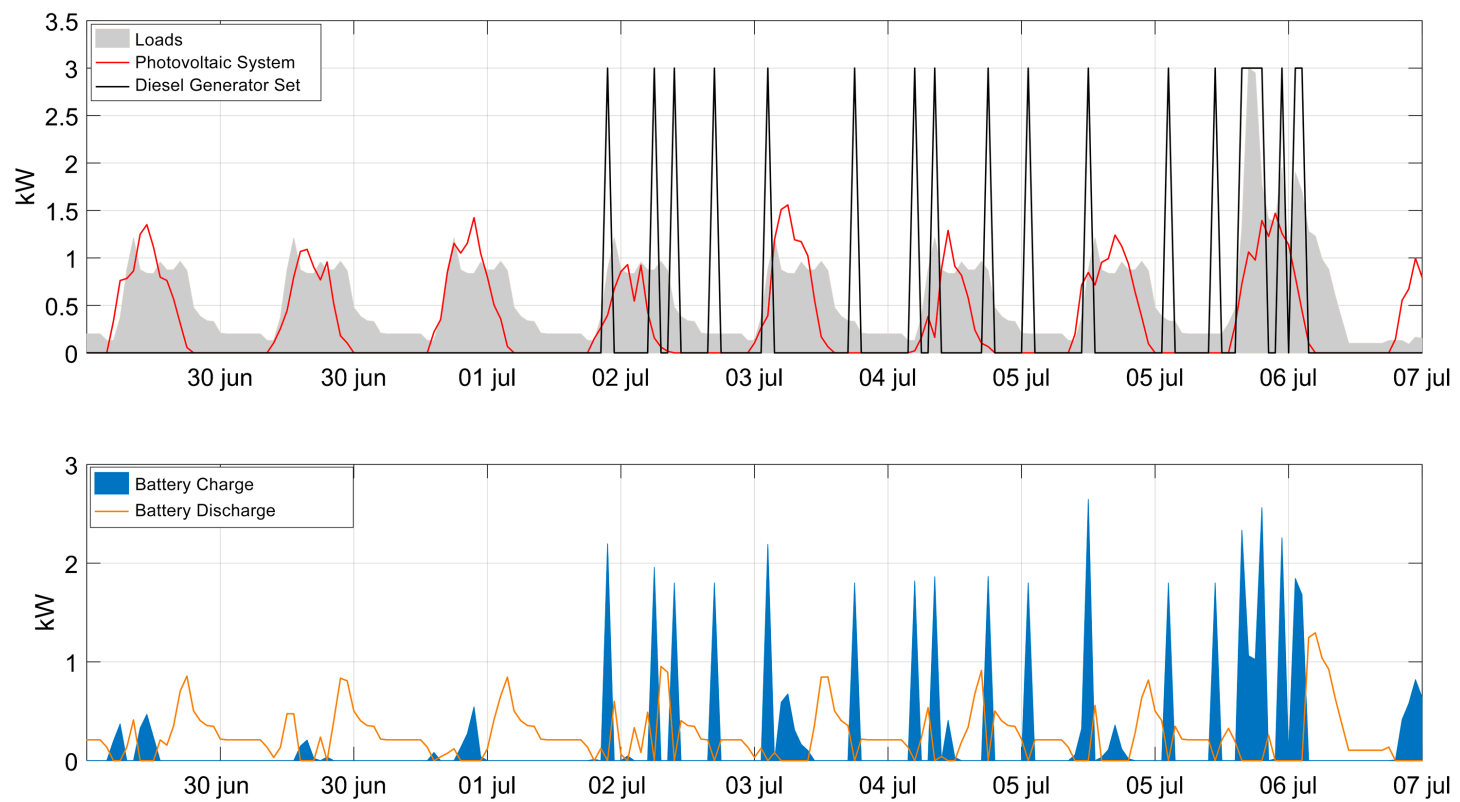

Figure 16. Performance of the hybrid system in days of higher load demand.

The diesel generator size permitted to meet the need for peak load demand and feed the building. The diesel generator operated for $200 \mathrm{~h}$, being activated 156 times throughout the year. Energy production of $500 \mathrm{kWh}$ /year, consuming a total of $239 \mathrm{~L}$, a yield of $21.3 \%$, and specific consumption of $0.478 \mathrm{~L} / \mathrm{kWh}$. Months with the highest incidence of activation were May, July, and September.

The results without using the battery bank show that the system was not viable because the renewable penetration by the PV system was only $13.4 \%$ and $86.6 \%$ of the diesel generator, causing an overproduction of electricity $89.9 \%$. The absence of the battery bank in the system caused stability problems. The option with only the photovoltaic system and batteries is not considered in any simulation by HOMER, as the autonomous system would not be able to meet the need for loads alone in times of significant variation when using the consumption profiles 3,4 and 5 .

Without using the hybrid energy system, the loads were supplied only by the isolated diesel generator, which is a well-known routine for energy supply in remote areas of the Amazon. However, the internal combustion engines generated a series of problems for the health of the population and the environment. Table 4 presents the results of emissions generated in the pure diesel energy systems and the hybrid PV-diesel system. Comparing the data from the two systems, HES presented considerable mitigation in the emission of harmful gases. The harmful effects of exposure of the population, fauna, and flora to the emitted gases are seen in Table 5.

Table 4. Comparison between emissions caused by diesel and hybrid PV-diesel systems.

\begin{tabular}{lcc}
\hline \multicolumn{1}{c}{ Quantity } & Diesel & PV/Diesel \\
\hline Carbon dioxide (kg/year) & 4499 & 592 \\
Carbon monoxide (kg/year) & 34.0 & 4.48 \\
Unburned hydrocarbons (kg/year) & 1.24 & 0.163 \\
Particule matter (kg/year) & 2.06 & 0.271 \\
Sulfur dioxide (kg/year) & 11.0 & 1.45 \\
Nitrogen oxides (kg/year) & 38.7 & 5.09 \\
\hline
\end{tabular}


Table 5. Harmful effects on health and the environment caused by the emission of polluting gases [77-81].

\begin{tabular}{lc}
\hline \multicolumn{1}{c}{ Pollutants } & Effects Caused \\
\hline $\begin{array}{l}\text { Carbon dioxide }\left(\mathrm{CO}_{2}\right) \\
\text { Carbon monoxide }(\mathrm{CO})\end{array}$ & $\begin{array}{c}\text { Air pollution, greenhouse effect imbalance, acid rain, cardiovascular } \\
\text { and respiratory diseases. }\end{array}$ \\
$\begin{array}{c}\text { Acts in the blood reducing oxygenation, nausea and intoxication. } \\
\text { Particule matter }(\mathrm{PM})\end{array}$ & $\begin{array}{r}\text { Precursors of the formation of tropospheric ozone and the potential } \\
\text { cause of greenhouse effect (methane). }\end{array}$ \\
Sulfur dioxide $\left(\mathrm{SO}_{2}\right)$ & $\begin{array}{c}\text { Respiratory cancer, lung inflammation and asthma symptoms. } \\
\text { In the body they cause respiratory problems like asthma and the } \\
\text { environment reacts with water in the atmosphere forming acid rain. } \\
\text { It causes pulmonary edema in the human body and the environment } \\
\text { prevents gas exchange, harming the process of photosynthesis. }\end{array}$ \\
\hline
\end{tabular}

\section{Conclusions}

The contribution of this work is the technical evaluation carried out on the existing local system, in which it shows that solar and diesel sources are viable components for application in HES in the region of Tapajós-Arapiuns Extractive Reserve in the Amazon region. However, the wind potential is not sufficient to provide success in power generation. In conclusion, the most suitable systems for replication in the region are HESs PV-Diesel or individual low-power systems with a solar energy system.

The case study, using the HOMER PRO Microgrid Analysis Tool software (version 3.12.0, Copyright (c) 2017, HOMER Energy LLC, Boulder, CO, USA), evaluated data such as energy balance, renewable generation potential, the behavior of eletrochemical batteries, the performance of the photovoltaic system, and the diesel generator set. This system is also a pilot project to be ideally replicated among communities in this region.

From the simulations it was possible to draw a synthetic load profile involving all five consumption profiles built with variation in daily demand. The dependence on diesel fuel is as small as possible. As a result, it was possible to observe that a significant part of the energy used by the loads, about $85.6 \%$, is provided by photovoltaic generation.

Through the sensitivity simulations for analysis of the daily variation of the load profile, it was possible to draw a minimum load profile for daily consumption in which the dependence of the diesel fuel is the smallest possible. With the synthetic load profile, it was possible to simulate variations in daily consumption of up to $50 \%$, avoiding the increase in peak demand. Therefore, changing load variability between days without increasing consumption decreases the hours of operation of the diesel generator. The results for sensitivity analysis also show that from the increase of demand in specific periods and overtime makes efficient management of energy consumption at peak times in March and April necessary.

Another contribution is that the results on the feasibility of using hybrid systems can be used by local entities to demand appropriate public policies for the region's reality. The replication of this HES promotes a solution to expand the project to universalize access to electricity in remote areas of the Amazon. It also adds economic development through the contribution of CEFA to the local population, which generates the quality of life as a result of this whole process.

Thus, the research will continue in other publications bringing real data for monitoring the generation and load systems, economic evaluation, and optimization of the HES.

Author Contributions: T.S.C. and M.G.V. contributed equally to this work. All authors have read and agreed to the published version of the manuscript.

Acknowledgments: This work was supported by the Coordination for the Improvement of Higher Education Personnel-Brazil (CAPES)-Financing Code 001, CNPq, FAPESP (2016/08645-9), BYD ENERGY through the PADIS Program, and collaboration of the Centro de Estudos Avançados de Promoção Social e Ambiental (Projeto Saúde e Alegria). 
Conflicts of Interest: The authors declare no conflict of interest.

\section{Abbreviations}

The following abbreviations are used in this manuscript:

$\begin{array}{ll}\text { AC } & \text { Alternating current } \\ \text { CEAPS } & \text { Centro de estudos avançados de promoção social e ambiental } \\ \text { CEFA } & \text { Centro experimental floresta ativa } \\ \text { DC } & \text { Direct current } \\ \text { DGS } & \text { Diesel generator set } \\ \text { HES } & \text { Hybrid Energy Systems } \\ \text { HOMER } & \text { Hybrid optimization of multiple energy resources } \\ \text { KiBaM } & \text { Kinetic battery model } \\ \text { MIGDI } & \text { Isolated electric energy generation and distribution system } \\ \text { NREL } & \text { National renewable energy laboratory } \\ \text { PV } & \text { Photovoltaic } \\ \text { SIGFI } & \text { Individual generation system of electricity with the intermittent source } \\ \text { SIN } & \text { Interconnected national system } \\ \text { SOC } & \text { State of charge } \\ \text { UN } & \text { United Nations }\end{array}$

\section{References}

1. Ritchie, H.; Roser, M. Access to Energy. In Our World in Data-University of Oxford. Available online: https: / / ourworldindata.org/ energy-access (accessed on 20 March 2020).

2. Bank, W. World Development Indicators Online Database. The World Bank Group. 2019. Available online: https: / / datacatalog.worldbank.org/dataset/world-development-indicators (accessed on 2 March 2020).

3. IEA. SDG7: Data and Projections. International Energy Agency. 2019. Available online: https://www.iea. org/reports/sdg7-data-and-projections (accessed on 2 March 2020).

4. Viana, C. Governo prevê prazo de 7 a 10 anos para que luz chegue a 72 mil famílias da Amazônia. Agência Câmara de Notícias. Available online: https:/ / www.camara.leg.br/noticias/617876-governo-preveprazo-de-7-a-10-anos-para-que-luz-chegue-a-72-mil-familias-da-amazonia.(accessed on 3 March 2020).

5. Pinho, J.T.; Barbosa, C.F.O.; Pereira, E.J.; Souza, H.M.S.; Blasques, L.C.M.; Galhardo, M.A.B.; Macêdo, W.N. Sistemas Híbridos—Soluções Energéticas Para a Amazônia; Ministério de Minas e Energia: Brasilia, Brazil, 2008.

6. Ameen, A.M.; Pasupuleti, J.; Khatib, T. Simplified performance models of photovoltaic/diesel generator/battery system considering typical control strategies. Energy Convers. Manag. 2015, 99, 313-325. [CrossRef]

7. Sechilariu, M.; Locment, F. Chapter 3-Backup Power Resources for Microgrid. In Urban DC Microgrid; Sechilariu, M., Locment, F., Eds.; Butterworth-Heinemann: Oxford, UK, 2016; pp. 93-132. [CrossRef]

8. Varella, C.A.A.; Santos, G.S. Noções Básicas de Motores a Diesel; 2010. Available online: http:/ / www.ufrrj.br/institutos/it/deng/varella/Downloads/IT154_motores_e_tratores/Literatura / No\%E7\%F5es\%20B\%E1sicas\%20de\%20Motores\%20Diesel.pdf (accessed on 23 November 2019).

9. Nehrir, M.H.; Wang, C.; Strunz, K.; Aki, H.; Ramakumar, R.; Bing, J.; Miao, Z.; Salameh, Z. A Review of Hybrid Renewable/Alternative Energy Systems for Electric Power Generation: Configurations, Control, and Applications. IEEE Trans. Sustain. Energy 2011, 2, 392-403. [CrossRef]

10. Journeay-Kaler, P.; Mofor, L. Hybrid Power Systems; International Renewable Energy Agency: Abu Dhabi, UAE, 2013.

11. Goodman, D. 20-Small modular reactors (SMRs): The case of developing countries. In Handbook of Small Modular Nuclear Reactors; Carelli, M.D., Ingersoll, D.T., Eds.; Woodhead Publishing Series in Energy, Woodhead Publishing: Cambridge, UK, 2015; pp. 485-500. [CrossRef]

12. De Campos, R.A.S. Modelagem e Simulação de Grupo Gerador a Diesel Consumindo óleo Vegetal "In Natura" Enriquecido com Hidrogênio e Oxigênio Visando Melhorar sua Eficiência Energética. Master's Thesis, Universidade Federal do Para, Belem, Brazil, 2015. 
13. Hauschild, L. Avaliação de Estratégias de Operação de Sistemas Híbridos Fotovoltaico-Eólico-Diesel. In Proceedings of the 2017 IEEE International Conference on Environment and Electrical Engineering and 2017 IEEE Industrial and Commercial Power Systems Europe, Milan, Italy, 6-9 June 2017; p. 117.

14. Lau, K.; Yousof, M.; Arshad, S.; Anwari, M.; Yatim, A. Performance analysis of hybrid photovoltaic/diesel energy system under Malaysian conditions. Energy 2010, 35, 3245-3255. [CrossRef]

15. De Oliveira Barbosa, C.F. Avaliação Tecnológica, Operacional e de Gestão de Sistemas híBridos Para Geração de Eletricidade na Região Amazônica. Master's Thesis, Universidade Federal do Para, Belem, Brazil, 2006.

16. Sandeep, G.; Vakula, V.S. Optimal combination and sizing of a standalone hybrid power system using HOMER. In Proceedings of the 2016 International Conference on Electrical, Electronics, and Optimization Techniques (ICEEOT), Chennai, India, 3-5 March 2016; pp. 4141-4144. [CrossRef]

17. Singh, A.; Baredar, P.; Gupta, B. Computational Simulation and Optimization of a Solar, Fuel Cell and Biomass Hybrid Energy System Using HOMER Pro Software. Procedia Eng. 2015, 127, 743-750, doi:10.1016/j.proeng.2015.11.408. [CrossRef]

18. Lal, D.; Bhusan Dash, B.; Akella, A. Optimization of PV/Wind/Micro-Hydro/Diesel Hybrid Power System in HOMER for the Study Area. Int. J. Electr. Eng. Inform. 2011, 3, 307-325. [CrossRef]

19. Asrari, A.; Ghasemi, A.; Javidi, H. Economic evaluation of hybrid renewable energy systems for rural electrification in Iran-A case study. Renew. Sustain. Energy Rev. 2012, 16. [CrossRef]

20. Scarlatache, F.; Grigoras, G.; Neagu, B.C.; Ciobanu, R.C. Aided decision making for hybrid energy systems planning in micro-grids. In Proceedings of the 2018 Smart City Symposium Prague (SCSP), Prague, Czech Republic, 24-25 May 2018; pp. 1-5. [CrossRef]

21. Vendoti, S.; Muralidhar, M.; Kiranmayi, R. HOMER Based Optimization of Solar-Wind-Diesel Hybrid System for Electrification in a Rural Village. In Proceedings of the 2018 International Conference on Computer Communication and Informatics (ICCCI), Coimbatore, India, 4-6 January 2018; pp. 1-6. [CrossRef]

22. Adetunji, K.; Akinlabi, O.; Joseph, M.K. Developing a Microgrid for Tafelkop Using HOMER. In Proceedings of the 2018 International Conference on Advances in Big Data, Computing and Data Communication Systems (icABCD), Durban, South Africa, 6-7 August 2018; pp. 1-6. [CrossRef]

23. Al-Hamdani, A.H.; Dawood, A.F.; Abdullah, K.N.; Mousaui, S.M. Optimal sizing of photovoltaic systems using HOMER for Baghdad. Int. J. Comput. Appl. Sci. 2016, 1, 1-6. [CrossRef]

24. Costa, T.S.; Narváez, D.I.; de Melo, K.B.; Villalva, M.G.; Pompermaier, D. Optimum design of autonomous PV-diesel-battery hybrid systems: Case study at Tapajós-Arapiuns extractive reserve in Brazil. In Proceedings of the 2019 IEEE PES Innovative Smart Grid Technologies Conference-Latin America (ISGT Latin America), Gramado, Brazil, 15-18 September 2019; pp. 1-6. [CrossRef]

25. Kumar, P.; Pukale, R.; Kumabhar, N.; Patil, U. Optimal Design Configuration Using HOMER. Procedia Technol. 2016, 24, 499-504, doi:10.1016/j.protcy.2016.05.085. [CrossRef]

26. Shaahid, S.; Elhadidy, M. Economic analysis of hybrid photovoltaic-diesel-battery power systems for residential loads in hot regions-A step to clean future. Renew. Sustain. Energy Rev. 2008, 12, 488-503. [CrossRef]

27. Deshmukh, M.K.; Deshmukh, S.S. Modeling of hybrid renewable energy system. Renew. Sustain. Energy Rev. 2008, 12, 235-249. [CrossRef]

28. Servasing, A.A.; Pahlevaninezhad, M.; Jain, P.K. A review of hybrid distributed generation systems. In Proceedings of the 2012 Intelec Conference, Scottsdale, AZ, USA, 30 September-4 October 2012.

29. MME. Manual para atendimento às regiões remotas dos sistemas isolados. Ministério Minas Energ. 2017, 1, 13.

30. ANEEL. Resolução Normativa N 493. Agência Nacional de Energia Elétrica 2012. Available online: http: //www2.aneel.gov.br/cedoc/ren2012493.pdf (accessed on 5 December 2019).

31. Costa, T.S. Estudo e simulação de sistemas fotovoltaicos híbridos para aplicação autônoma e conectada à rede Master's Thesis, Universidade Estadual de Campinas, Campinas, Brazil, 2019.

32. Francisquini, A.A. Estimação de Curvas de Carga em Pontos de Consumo e em Transformadores de Distribuição. Master's Thesis, Universidade Estadual Paulista, São Paulo, Brazil, 2006.

33. De Oliveira, L.A.A. Tratamento de Dados de Curvas de Carga via Análise de Agrupamentos e Transformada Wavelets. Ph.D. Thesis, COPPE/Programa de Engenharia de sistemas e computação, Universidade Federal do Rio de Janeiro, Rio de Janeiro, Brazil, 2013.

34. Ashari, M.; Nayar, C.V. An optimum dispatch strategy using set points for a photovoltaic (PV)-diesel-battery hybrid power system. Sol. Energy 1999, 66, 1-9. [CrossRef] 
35. Mohammed, A.; Pasupuleti, J.; Khatib, T.; Elmenreich, W. A review of process and operational system control of hybrid photovoltaic/diesel generator systems. Renew. Sustain. Energy Rev. 2015, 44, 436-446. [CrossRef]

36. Ribeiro, L.; Saavedraa, O.R.; Matos, J.G.; Lima, S.L.; Bonan, G.; Martins, A.S. Controle e operação de um sistema híbrido de geração de energia elétrica a partir de fontes renováveis. XVIII Congresso Brasileiro de Automática, 2010. Available online: https://www.sba.org.br/web/paginas/view?id=12 (accessed on 23 January 2020).

37. Fakham, H.; Lu, D.; Francois, B. Power Control Design of a Battery Charger in a Hybrid Active PV Generator for Load-Following Applications. IEEE Trans. Ind. Electron. 2011, 58, 85-94. [CrossRef]

38. Schmitt, W. Modeling and simulation of photovoltaic hybrid energy systems-optimization of sizing and control. In Proceedings of the Conference Record of the Twenty-Ninth IEEE Photovoltaic Specialists Conference, New Orleans, LA, USA, 19-24 May 2002; pp. 1656-1659.

39. Rakesh, S.; Digbijoy, M.; Tanushree, M.; Nishant, P. Designing and Study Standalone Hybrid Energy System: For Technical Institutes. Int. J. Inf. Res. Rev. 2016, 3, 2192-2197.

40. Pinho, J.T.; Galdino, M.A. Manual de Engenharia Para Sistemas Fotovoltaicos, 1st ed.; CRESESB: Rio de Janeiro, Brazil, 2014.

41. Sinha, S.; Chandel, S. Review of software tools for hybrid renewable energy systems. Renew. Sustain. Energy Rev. 2014, 32, 192-205. [CrossRef]

42. De Souza Silva, J.L.; Costa, T.S.; de Melo, K.B.; Sakô, E.Y.; Moreira, H.S.; Villalva, M.G. A Comparative Performance of PV Power Simulation Software with an Installed PV Plant. In Proceedings of the 2020 IEEE International Conference on Industrial Technology (ICIT), Buenos Aires, Argentina, 26-28 February 2020; pp. 531-535.

43. Grover, A. Study of diferent simulation softwares for optimization and economic analysis of photovoltaic system. Int. J. Adv. Res. 2019, 7, 1163-1170. [CrossRef]

44. Crawley, D.B.; Hand, J.W.; Kummert, M.; Griffith, B.T. Contrasting the capabilities of building energy performance simulation programs. Build. Environ. 2008, 43, 661-673, doi:10.1016/j.buildenv.2006.10.027. [CrossRef]

45. Shukla, A.K.; Sudhakar, K.; Baredar, P. Simulation and performance analysis of $110 \mathrm{kWp}$ grid-connected photovoltaic system for residential building in India: A comparative analysis of various PV technology. Energy Rep. 2016, 2, 82-88. [CrossRef]

46. Psomopoulos, C.S.; Ioannidis, G.C.; Kaminaris, S.D.; Mardikis, K.D.; Katsikas, N.G. A Comparative Evaluation of Photovoltaic Electricity Production Assessment Software (PVGIS, PVWatts and RETScreen). Environ. Process. 2015, 2. [CrossRef]

47. Kumar, P. Analysis of Hybrid Systems: Software Tools. In Proceedings of the 2016 2nd International Conference on Advances in Electrical, Electronics, Information, Communication and Bio-Informatics (AEEICB), Chennai, India, 27-28 February 2016; doi:10.1109/AEEICB.2016.7538302. [CrossRef]

48. Kamalakannan, C.; Suresh, L.; Dash, S.; Panigrahi, B. Power Electronics and Renewable Energy Systems: Proceedings of ICPERES 2014; Lecture Notes in Electrical Engineering; Springer India: Berlin/Heidelberg, Germany, 2014.

49. Fathima, H.; Prabaharan, N.; Palanisamy, K.; Kalam, A.; Mekhilef, S.; Justo, J.J. Hybrid-Renewable Energy Systems in Microgrids: Integration, Developments and Control; Woodhead Publishing Series in Energy, Elsevier Science: Amsterdam, The Netherlands, 2018.

50. Muh, E.; Tabet, F. Comparative analysis of hybrid renewable energy systems for off-grid applications in Southern Cameroons. Renew. Energy 2019, 135, 41-54. [CrossRef]

51. Swarnkar, N.M.; Gidwani, L.; Sharma, R. An application of HOMER Pro in optimization of hybrid energy system for electrification of technical institute. In Proceedings of the 2016 International Conference on Energy Efficient Technologies for Sustainability (ICEETS), Nagercoil, India, 7-8 April 2016; pp. 56-61.

52. Oulis Rousis, A.; Tzelepis, D.; Konstantelos, I.; Booth, C.; Strbac, G. Design of a Hybrid AC/DC Microgrid Using HOMER Pro: Case Study on an Islanded Residential Application. Inventions 2018, 3, 55. [CrossRef]

53. Zahboune, H.; Zouggar, S.; Krajacic, G.; Varbanov, P.S.; Elhafyani, M.; Ziani, E. Optimal hybrid renewable energy design in autonomous system using Modified Electric System Cascade Analysis and Homer software. Energy Convers. Manag. 2016, 126, 909-922. [CrossRef] 
54. Deshmukh, M.; Singh, A.B. Modeling of Energy Performance of Stand-Alone SPV System Using HOMER Pro. Energy Procedia 2019, 156, 90-94, doi:10.1016/j.egypro.2018.11.100. [CrossRef]

55. Antonio Barrozo Budes, F.; Valencia Ochoa, G.; Obregon, L.G.; Arango-Manrique, A.; Ricardo Núñez Álvarez, J. Energy, Economic, and Environmental Evaluation of a Proposed Solar-Wind Power On-grid System Using HOMER Pro®: A Case Study in Colombia. Energies 2020, 13, 1662. [CrossRef]

56. Micangeli, A.; Del Citto, R.; Kiva, I.; Santori, S.; Gambino, V.; Kiplagat, J.; Viganò, D.; Fioriti, D.; Poli, D. Energy Production Analysis and Optimization of Mini-Grid in Remote Areas: The Case Study of Habaswein, Kenya. Energies 2017, 10, 2041. [CrossRef]

57. Madziga, M.; Rahil, A.; Mansoor, R. Comparison between Three Off-Grid Hybrid Systems (Solar Photovoltaic, Diesel Generator and Battery Storage System) for Electrification for Gwakwani Village, South Africa. Environments 2018, 5, 57. [CrossRef]

58. Jiang, F.; Xie, H.; Ellen, O. Hybrid Energy System with Optimized Storage for Improvement of Sustainability in a Small Town. Sustainability 2018, 10, 2034. [CrossRef]

59. Anastasopoulou, A.; Butala, S.; Patil, B.; Suberu, J.; Fregene, M.; Lang, J.; Wang, Q.; Hessel, V. Techno-Economic Feasibility Study of Renewable Power Systems for a Small-Scale Plasma-Assisted Nitric Acid Plant in Africa. Processes 2016, 4, 54. [CrossRef]

60. Dawood, F.; Shafiullah, G.; Anda, M. Stand-Alone Microgrid with 100\% Renewable Energy: A Case Study with Hybrid Solar PV-Battery-Hydrogen. Sustainability 2020, 12, 2047. [CrossRef]

61. Oviroh, P.; Jen, T.C. The Energy Cost Analysis of Hybrid Systems and Diesel Generators in Powering Selected Base Transceiver Station Locations in Nigeria. Energies 2018, 11, 687. [CrossRef]

62. Shoeb, M.; Shafiullah, G. Renewable Energy Integrated Islanded Microgrid for Sustainable Irrigation-A Bangladesh Perspective. Energies 2018, 11, 1283. [CrossRef]

63. Ali, S.; Jang, C.M. Optimum Design of Hybrid Renewable Energy System for Sustainable Energy Supply to a Remote Island. Sustainability 2020, 12, 1280. [CrossRef]

64. El-houari, H.; Allouhi, A.; Rehman, S.; Buker, M.S.; Kousksou, T.; Jamil, A.; El Amrani, B. Design, Simulation, and Economic Optimization of an Off-Grid Photovoltaic System for Rural Electrification. Energies 2019, 12, 4735. [CrossRef]

65. Tribioli, L.; Cozzolino, R.; Evangelisti, L.; Bella, G. Energy Management of an Off-Grid Hybrid Power Plant with Multiple Energy Storage Systems. Energies 2016, 9, 661. [CrossRef]

66. Lambert, T.; Gilman, P.; Lilienthal, P. Micropower System Modeling with HOMER: Integration of Alternative Sources of Energy; John Wiley \& Sons, Inc.: Hoboken, NJ, USA, 2006.

67. Manwell, J.F.; McGowan, J.G. Lead acid battery storage model for hybrid systems. Sol. Energy 1993, 50, 333-341. [CrossRef]

68. Filho, G.J.L. Previsão da Autonomia de Baterias de Chumbo-ácido Aplicadas a Sistemas Híbridos de Geração de Energia Utilizando o Método KiBaM. Master's Thesis, Universidade Federal de Pernambuco, Recife, Brazil, 2017.

69. HOMER. Homer User Manual. Available online: https://www.homerenergy.com/products/pro/docs / latest/index.html (accessed on 10 December 2019).

70. Moghaddam, S.; Bigdeli, M.; Moradlou, M.; Siano, P. Designing of stand-alone hybrid PV/wind/battery system using improved crow search algorithm considering reliability index. Int. J. Energy Environ. Eng. 2019. [CrossRef]

71. Khatib, T.; Elmenreich, W. Modeling of Photovoltaic Systems Using MATLAB: Simplified Green Codes; John Wiley \& Sons: Hoboken, NJ, USA, 2016; pp. 213-217. [CrossRef]

72. Yamegueu, D.; Azoumah, Y.; Py, X. Experimental and economical study of sustainable electricity generation by solar PV/diesel hybrid systems without storage for off grid areas. WIT Trans. Ecol. Environ. 2011, 143, 37-49. [CrossRef]

73. Rampinelli, G.A.; da Silva, M.P.; Marcelino, R. Instalação e monitoramento de uma estação metereologica de superficie automatica de uma planta piloto bioclimatica. In XXIII Simposio Peruano de Energía Solar y del Ambiente; 2016. Available online: http:/ /xxiiispes.perusolar.org/wp-content/uploads/2016/10/PonenciaN\%C2\%AA-39-Viernes-307.pdf (accessed on 15 December 2019).

74. Empresa de Pesquisa Energética, E. Consumo Anual de Energia Elétrica por classe (nacional). In Empresa de Pesquisa Energética; 2018. Available online: https://www.epe.gov.br/pt/publicacoes-dados-abertos/ publicacoes / Consumo-Anual-de-Energia-Eletrica-por-classe-nacional (accessed on 10 November 2019). 
75. Grubb, M.; Meyer, N. Wind Energy: Resources, Systems, and Regional Strategies; Island Press: Washington, DC, USA, 1993.

76. Feitosa, E.A.N.; Pereira, A.L.; Silva, G.R.; Veleda, D.R.A.; Silva, C.C. Panorama do Potencial Eólico no Brasil; ANEEL: Brasília, Brazil, 2003.

77. Krahl, J.; Munack, A.; Schröder, O.; Stein, H.; Bünger, J. Influence of Biodiesel and Different Designed Diesel Fuels on the Exhaust Gas Emissions and Health Effects. SAE Trans. 2003, 112, 2447-2455.

78. Markandya, A.; Wilkinson, P. Electricity generation and health. Lancet 2007, 370,979-990. [CrossRef]

79. Markandya, A.; Armstrong, B.G.; Hales, S.; Chiabai, A.; Criqui, P.; Mima, S.; Tonne, C.; Wilkinson, P. Public health benefits of strategies to reduce greenhouse-gas emissions: Low-carbon electricity generation. Lancet 2009, 374, 2006-2015. [CrossRef]

80. McMichael, A.J.; Woodruff, R.E.; Hales, S. Climate change and human health: Present and future risks. Lancet 2006, 367, 859-869. [CrossRef]

81. Haines, A.; McMichael, A.J.; Smith, K.R.; Roberts, I.; Woodcock, J.; Markandya, A.; Armstrong, B.G.; Campbell-Lendrum, D.; Dangour, A.D.; Davies, M.; et al. Public health benefits of strategies to reduce greenhouse-gas emissions: Overview and implications for policy makers. Lancet 2009, 374, 2104-2114. [CrossRef]

(C) 2020 by the authors. Licensee MDPI, Basel, Switzerland. This article is an open access article distributed under the terms and conditions of the Creative Commons Attribution (CC BY) license (http:/ / creativecommons.org/licenses/by/4.0/). 